\title{
Political Threat, Ideology, and Conspiracy Endorsement
}

\author{
Stephen P. Schneider \\ Carl R. Woese Institute for Genomic Biology \\ University of Illinois at Urbana-Champaign \\ 1206 W. Gregory Dr. \\ Urbana, IL 6180 \\ ss145@illinois.edu \\ Ingrid J. Haas \\ Department of Political Science \\ Center for Brain, Biology, \& Behavior \\ University of Nebraska—Lincoln \\ Oldfather Hall \\ Lincoln, NE 68588 \\ ihaas2@unl.edu
}

Manuscript in preparation (February 2020). Please do not cite.

\begin{abstract}
Recent U.S. Presidential elections were unusual in the number of unsubstantiated claims made about the candidates and government in general. While conspiracy theories are sometimes dismissed as existing only on the fringes of American society, more recent research has suggested that even average Americans endorse some conspiracy theories on occasion. Although scholars have suggested that the ideological undertones of conspiratorial beliefs shift with presidential election outcomes, little work has examined the mechanism linking political ideology to conspiratorial beliefs. In this paper, we examine whether perceived political threat increases the likelihood that individuals will support ideologically-relevant conspiracy theories using three studies. In Study 1 and Study 2, we examine how political threat impacts the endorsement of conspiracy theories before and after the 2016 U.S. presidential election. In Study 3 , we use an experimental design to manipulate political threat and measure conspiracy theory endorsement. We find that the reasons for endorsing conspiracy theories may shift over time as a function of current motivation to endorse or support ideas that benefit one's political ingroup and that political threat is an important mechanism for understanding why political identity is sometimes associated with endorsement of conspiracies.
\end{abstract}

Keywords: Motivated Reasoning, Political Conspiracy Theories, Threat, Political Ideology 
Conspiracy theories were not only commonplace during recent U.S. presidential elections and their aftermaths (see Uscinski, 2016; Ghaffary, 2020) but have been endemic to American politics since its founding (Hofstadter, 1964; Uscinski \& Parent, 2014). Far from existing only on the fringes of society, conspiratorial narratives are popular among the American public (Oliver \& Wood, 2014). There is, however, an ongoing debate about the psychological motives for conspiracy endorsement. To this debate, we add that specific emotions can compel people to endorse political conspiracy theories. Specifically, we combine insight from motivated reasoning with literature examining how emotion affects political cognition to suggest that fear is driving conspiratorial thinking. We suggest that when an individual's political party loses an election, the loss triggers feelings of threat from government, which motivates the endorsement of conspiracy theories targeting political opponents.

Scholars who study conspiracy theories have suggested motivated reasoning as a useful framework for understanding political conspiracy endorsement (e.g., Douglas et al., 2019; Douglas \& Sutton, 2020; Miller, Saunders, \& Farhart, 2015; Flynn, Nyhan, \& Reifler, 2017; but see Edelson et al., 2017). Directional motivated reasoning occurs when people seek out information that supports their pre-existing attitudes or desired conclusions (Kunda, 1990; Taber \& Lodge, 2006), as opposed to an open-minded consideration of information. In the politics realm, political ideology or partisanship may bias information processing in that information will be interpreted through the lens of one's political attitudes or affiliation (Bolsen, Druckman, \& Cook, 2014). Past work has found evidence of a link between motivated reasoning and conspiracy endorsement. For example, scholars have found that political conspiracy theories are commonly supported on both the political left and right (Hopp \& Vargo, 2019; Uscinski \& Parent, 2014; Van Prooijen, Krouwel, \& Pollet, 2015). One factor affecting motivated reasoning 
and conspiracy theory endorsement could be how an individual's preferred candidate fares during an election (Edelson et al., 2017; Uscinski \& Parent, 2014) with supporters of losing candidates being more likely to use conspiracy theories to explain or understand the loss (Uscinski \& Parent, 2014). Miller, Saunders, and Farhart (2015) found support for the idea that the electoral loss of one's preferred candidate precipitates motivated reasoning and conspiracy theory endorsement in that conservatives were more likely to believe conspiracy theories while President Obama was in office. However, the assertion that electoral losses trigger motivated reasoning and the endorsement of political conspiracy theories implies a link between emotion and political conspiracy endorsement, which has not been tested directly.

Given the apparent link between motivated reasoning and conspiratorial thinking, it may be the case that specific emotions such as fear from threats to one's political ideology or ingroup drives conspiracy endorsement. Prior work examining the impact of threat on political cognition has shown that threat often increases individuals' reliance on information sources that are congruent with prior attitudes (Lavine et al., 2005), authoritarian thinking (Hetherington \& Suhay, 2011), hostility toward outgroup members (See \& Petty, 2006), and intolerance (Haas \& Cunningham, 2014). Some scholars have suggested that people endorse conspiracy theories to gain a sense of control (e.g., Abalakina-Paap et al.,1999; Douglas, Sutton, \& Chichoka, 2017; Marchlewska, Chichocka, \& Kossowska, 2018; Sullivan et al., 2010; van Prooijen \& Acker, 2015). Gaining a sense of control may reduce threat. However, these studies have neither directly tested whether threat drives conspiracy endorsement nor examined the role of political ideology on conspiracy endorsement. Moreover, the limited empirical work examining the link between control and conspiracy endorsement, like much of the work examining conspiracy theory endorsement, tends to be observational, which prevents causal conclusions (Douglas et al., 2019; 
but see van Prooijen \& Acker, 2015).

\section{Present Study}

In the present work, we argue that political threat should lead to greater endorsement of conspiracy theories. Furthermore, endorsement of ideological conspiracy theories (i.e., those that are politically relevant and appeal to ideological factions) should be driven by a combination of threat and motivated reasoning. When politically threatened, conservatives should be more likely to endorse conspiracy theories about liberals, and threatened liberals should be more likely to endorse conspiracy theories about conservatives. We use Wood and colleagues' (2012) definition of conspiracy theories as a "proposed plot by powerful people or organizations working together in secret to accomplish some (usually sinister) goal" (p. 767). ${ }^{1}$ To test these hypotheses, we conducted three studies. The first two studies use the 2016 United States Presidential election as a natural experiment, relying on convenience samples. For these studies, we collected data on political threat, ideology, and conspiracy endorsement before and after the general election in November 2016. In a third study, we sought to move beyond the use of observational studies commonly used in the work examining conspiracy theory endorsement to understand whether political threat causes the endorsement of political conspiracy theories. To do this, we used a survey experiment to manipulate partisan threat and measured conspiracy theory endorsement in a representative sample of Americans.

\section{Methods - Study 1 and 2}

\section{Participants}

Participants in the first study were recruited through Amazon's Mechanical Turk (AMT) at three time points, comprising three independent samples. Although AMT samples tend to be

\footnotetext{
${ }^{1}$ This definition is agnostic to the veracity of conspiratorial ideas. In other words, we do not adjudicate here on whether specific conspiracy theories may or may not be true.
} 
less representative of the U.S. population than a national probability sample, they do tend to be more representative than student samples (Berinsky et al. 2012; Levay et al. 2016). Given our interest in the psychological mechanism underlying endorsement (rather than the frequency of this behavior in the population) and our interest in obtaining time-sensitive election data, obtaining a representative sample was not our primary focus in the first two studies. The first sample was obtained one week before Election Day (November 2-3, 2016; $n=315)^{2}$. The second sample was collected one week after the election (November 15-16; $n=164$ ). Finally, the third sample was collected one month after the election (December 19; $n=125$ ). Participants were compensated \$0.75 USD. Overall, participants recruited for the three AMT samples were slightly liberal (ideology: $1=$ very liberal, $7=$ very conservative; $M=3.318, S D=1.720)$, young $(M=$ 33.92, $S D=9.885)$, male (59\%), and fairly educated (Mode = "Bachelor's degree"; see Appendix for descriptive statistics).

University students enrolled in introductory political science courses between November 2016 and April 2017 participated in the second study in exchange for course credit. Unlike the first study, data for the second study were collected continuously from before the election to month after the election. Data was then collected five months after the election to examine whether the effects observed closer to the election were present several months after the election. For analysis and comparison to data from Study 1, this data was partitioned relative to the election (Time 1: Pre-Election, November 1-8, 2016, $n=160$; Time 2: Post-Election, November $9^{\text {th }}$ to December $2^{\text {nd }}, 2016, n=212$; Time 3: five months after the election, April 7-21, 2017, $n=297$ ). Participants recruited for the student sample were almost evenly split in gender

\footnotetext{
${ }^{2}$ Participants at Time 1 also completed a failed manipulation of political threat that had no impact on variables of interest and will not be discussed further. In all three studies, participants also completed measures of powerlessness and uncertainty. These items were not used in the analysis reported here.
} 
$($ male $=48 \%)$ and ideology $(1=$ very liberal, $7=$ very conservative, $M=4.127, S D=1.827)$.

\section{Materials and Procedure}

Participants in both studies completed three scales designed to measure endorsement of conspiracy theories. The first scale measured general conspiracy endorsement using fifteen items not tied to a specific political ideology or party (Brotherton et al., 2013). We developed two additional conspiracy endorsement scales that were designed to appeal more to liberals or conservatives, specifically. To create the ideological conspiracy scales, we generated a list of forty conspiracies that either a liberal or conservative might endorse. We then recruited a separate online sample from Prolific Academic ( $n=166$, data collected October 14-16, 2016), who rated the conspiracies using two criteria: which political ideology was most likely to believe the conspiracy $(1=$ liberal, $7=$ conservative $)$ and how believable the conspiracy theory was $(1=$ Extremely believable and $7=$ Extremely unbelievable). We used these ratings to select ten conspiracies that the participants thought liberals would endorse and ten that conservative would endorse that were balanced on mean believability (liberal $=4.10$, conservative $=4.12$ ). Both ideological scales included conspiracies about the 2016 U.S. presidential candidates (Hillary Clinton and Donald Trump), as well as broad conspiracies that appeal to ideological values and beliefs (see Appendix for items) ${ }^{3}$.

Items from all three conspiracy scales were presented in a randomized order. In studies 1 and 2, respondents were asked to evaluate each of the conspiracy theories based on the likelihood it was true (five-point scale: $1=$ Definitely not true, $5=$ Definitely true). The three scales were reliable in both datasets (Study 1: general $\alpha=0.93, M=2.690, S D=0.882$, liberal $\alpha=0.80, M=$ 3.303, $S D=0.714$, conservative $\alpha=0.90, M=2.234, S D=0.953$; Study 2 : general $\alpha=0.90, M$

\footnotetext{
${ }^{3}$ Participant in each of the studies were told that "the statements have a high probability of being false, but we cannot make any claims about the accuracy of any one individual item" at the end of the survey.
} 
$=2.570, S D=0.726$, liberal $\alpha=0.83, M=2.801, S D=0.702$, conservative $\alpha=0.88, M=2.381$, $S D=0.832$ ), and mean composite scores were used for analysis.

Political threat was measured using two items presented in a randomized order.

Participants rated how threatened they felt by the government and politicians in government (five-point scale with 1 = very unthreatened, 5 = very threatened). The two items were strongly correlated (Study 1: $r=0.77, p<0.01$; Study 2: $r=0.75, p<0.001$ ) and were combined (Study 1: $M=3.041, S D=1.012 ;$ Study $2: M=2.719, S D=0.894)$ and mean-centered for analysis.

Participants self-reported their political ideology on a seven-point scale $(1=$ very liberal, $7=$ very conservative, Study $1: M=3.318, S D=1.720 ;$ Study $2: M=4.127, S D=1.827)$.

Respondents also completed a series of demographic questions that included: age, education, race $($ dummy coded, $1=$ white, $0=$ all other races $)$, gender $(1=$ female, $0=$ male $)$, and income .

Finally, a time variable was created to distinguish when the participant completed the survey. Time is not directly comparable between studies (see above for differences between studies and Figure 1), but was standardized to facilitate comparisons across studies, so that Time 1 (T1) corresponded with before the 2016 U.S. Presidential election in both samples, Time 2 (T2) was collected immediately after the election in Study 1 and in Study 2, and Time 3 (T3) a month after the election in Study 1 and five months after the election in Study 2. In both studies, time was coded as a categorical variable with Time 1 as the comparison category.

\{Figure 1 here

\section{Study 1 Results}

It was hypothesized that perceived political threat would lead to increased conspiracy endorsement. We expected that liberals would be more likely to endorse conspiracies about conservatives (what we are calling liberal conspiracy theories) and conservatives would endorse 
conspiracies about liberals (conservative conspiracy theories). We also expected that this ideologically motivated endorsement should increase with threat, such that threat would moderate the effect of ideology on endorsement. Given that Donald Trump (R) won the 2016 U.S. Presidential election we expected that liberal endorsement of conspiracy theories to increase over time while conservative endorsement of conspiracy theories would decrease. These effects should be due to conservatives experiencing reduced threat relative to liberals following the election of Donald Trump.

Overall, conservative participants reported higher levels of threat than liberals $(F(1,497)$ $=6.182, p=0.013)$. However, this main effect was moderated by time $(F(2,493)=8.255, p<$ $.001)$, such that for conservatives, threat decreased significantly from before $(M=.27, S D=.94)$ to immediately after $(M=.05, S D=.90)$ the election $(t(142.14)=1.942, p=0.054)$ and from before the election to a month after $(M=-.10, S D=1.15)$ the election $(t(165.52)=2.934, p=$ 0.004). The difference between immediately after the election and a month after the election was not significant $(t(189.99)=0.976, p=0.33)$. For liberals, threat increased significantly from before $(M=-.26, S D=1.03)$ to immediately following the election $(M=.20, S D=.87 ; t(723.46)$ $=-6.885, p<0.001)$ but decreased from immediately after the election to a month after the election $(M=-.06, S D=1.07 ; t(461.86)=3.112, p=0.002)$. However, threat a month after the election was higher than it was before the election for liberals $(t(468.52)=-2.486, p=0.013)$. This pattern is consistent with what one might expect following the course of the 2016 U.S. Presidential election. Conservative participants' level of threat peaked before the election before decreasing after Donald Trump was elected. However, for liberals, threat peaked right after Trump's election and did recede a month after the election but not to pre-election levels. The pattern of threat peaking for conservative participants before the election and for liberal 
participants right after the election is consistent with what one would expect given that Hillary Clinton was forecasted by most pollsters to win the 2016 Presidential election (e.g., Katz, 2016; Silver, 2016).

To test our primary hypotheses, we ran a mixed effects ANOVA which allowed us to model conspiracy type (general, liberal, conservative) as a within-subject factor and participant ideology, threat, and time as between-subject factors, controlling for age, education, sex, race, and income. We then used stepwise OLS regression models to decompose significant interactions of interest for each of the three conspiracy types using main effects, two-way interaction, and three-way interaction models (see Cohen et al., 2003). Results were interpreted from the first step in the model in which they appeared (see Appendix for full models).

\section{The Effects of Threat and Ideology on Conspiracy Endorsement}

First, we examined the main effects of threat and ideology on overall conspiracy endorsement (collapsed across conspiracy type). As expected, higher levels of threat $(F(1,482)=$ 125.412, $p<0.001$ ) predicted greater conspiracy endorsement, as did political conservatism $(F(1,482)=48.433, p<0.001)$. The relationship between ideology and conspiracy endorsement did not vary as a function of threat $(F(1,482)=1.201, p=.27)$, consistent with the view that threat increased endorsement for both liberal and conservative participants.

Next, we examined whether conspiracy type influenced the extent to which participant ideology predicted endorsement. There was a significant ideology by type of conspiracy interaction $(F(2,974)=399.96, p<0.001)$. As expected, conservative participants were more likely to endorse conspiracy theories about liberals $(b=0.329, S E=0.017, p<0.001)$ and general conspiracy theories $(b=0.108, S E=0.019, p<0.001)$, whereas liberal participants were 
more likely to endorse conspiracy theories about conservatives $(b=-0.135, S E=0.015, p<$ 0.001), suggesting that the ideological conspiracy endorsement scales worked as intended.

\{Figure 2 here

\section{Changes in Conspiracy Endorsement over Time}

Next, we examined whether the relationship between threat, participant ideology, and conspiracy endorsement was influenced by the 2016 U.S. Presidential election outcome. Consistent with the expectation that the election would have an impact was a significant fourway interaction of threat, ideology, conspiracy type, and time $(F(4,974)=3.03, p=0.017$; see Figure 2). To decompose this interaction effect, we used stepwise OLS regression models described above.

General Conspiracy Endorsement. The impact of threat on general conspiracy endorsement was fairly stable (see Figure $2 a)$. Threat predicted endorsement $(b=0.298, S E=$ $0.032, p<0.001$ ), and this effect was fairly stable over time (T1 vs. T2: $b=-0.066, S E=0.088, p$ $=0.455 ; \mathrm{T} 1$ vs. T3: $b=-0.132, S E=0.074, p=0.075)$. Political ideology also predicted general conspiracy endorsement $(b=0.108, \mathrm{SE}=0.019, p<0.001)$ with conservatives endorsing these items more than liberals. There was a marginal interaction of threat and participant ideology $(b=$ $-0.032, S E=0.018, p=0.077)$, but the nature of this interaction differed from before to right after the election (T1 vs. T2: $b=0.153, S E=0.053, p=0.004$ ). Before the election, liberals showed a stronger relationship between threat and endorsement of general conspiracies $(\mathrm{T} 1: b=-$ 0.058, $S E=0.025, p=0.021)$, while right after the election conservatives showed a stronger relationship between threat and endorsement (T2: $b=0.094, S E=0.048, p=0.054)$. This shift was temporary, however, and a month after the election the interaction between threat and 
ideology was similar to the interaction observed before the election (T1 vs. T3: $b=0.008, S E=$ $0.041, p=0.83)$

Liberal Conspiracy Endorsement. Threat also predicted liberal conspiracy endorsement (i.e., conspiracies targeting conservatives; see Figure $2 b ; b=0.239, S E=0.026, p<0.001$ ) and this main effect was not moderated by time (T1 vs T2: $b=0.09, S E=0.071, p=0.203$; T1 vs T3: $b=-0.007, S E=0.059, p=0.726)$. The threat by ideology interaction approached statistical significance $(b=-.027, S E=.015, p=0.07)$ with the effect of threat on endorsement being stronger for liberals and weaker for conservatives. The nature of the interaction between threat and ideology shifted from before to right after the election (T1 vs. T2: $b=0.103, S E=0.043, p=$ 0.017). Before the election, the relationship between threat and endorsement was stronger for liberals than conservatives (T1: $b=-0.046, S E=0.021, p=0.031)$, but this effect was not present right after the election (T2: $b=0.053, S E=0.036, p=0.152)$. As above, this shift was temporary and a month after the election the interaction between threat and ideology was similar to that observed before the election (T1 vs. T3: $b=0.014, S E=0.032, p=0.676$ ).

Conservative Conspiracy Endorsement. The pattern observed for conservative conspiracy theories (i.e., conspiracies targeting liberals) differed from those found for general and liberal conspiracy endorsement (see Figure 2c). As above, threat predicted conservative conspiracy endorsement $(b=.203, S E=.029, p<0.001)$, but here time did moderate the main effect of threat on endorsement. The relationship between threat and conservative conspiracy endorsement differed from before to right after the election (T1 vs. T2: $b=-0.195, S E=0.079, p=0.013$ ) and from before to a month after the election (T1 vs. T3: $b=-0.222, S E=0.066, p<0.001$ ). This pattern suggests that threat was a significantly weaker motivator of the endorsement of conservative conspiracies after Trump won the election. Conservative conspiracy endorsement 
was also different from general and liberal conspiracy endorsement in that the impact of threat on endorsement was not moderated by participant ideology $(b=0.013, S E=0.016, p=0.395)$. Before the election, endorsement of conservative conspiracies was explained by main effects of both threat $(\mathrm{T} 1: b=0.329, S E=0.042, p<0.001)$ and ideology $(\mathrm{T} 1: b=0.293, S E=0.024, p<$ 0.001), but after the election endorsement of conservative conspiracy theories was just a function of participant ideology, such that more conservative participants were more likely to endorse these statements (T2: $b=0.342, S E=0.037, p<0.001$; T3: $b=0.36, S E=0.034, p<0.001$ ).

\section{Study 2 Results}

We ran similar analyses with the student sample, in order to replicate the effects of Study 1 and examine the pattern on a longer timescale, given that Study 2 included data collected several months after the 2016 Presidential election. In Study 2, liberal participants reported higher levels of threat than conservatives $(F(1,1693)=56.64, p<0.001)$, which was opposite the pattern found in Study 1. Similar to the results found in Study 1, the main effect of participant ideology on threat was moderated by time $(F(2,559)=10.863, p<0.001)$. For conservatives, threat did not change from before $(M=.15, S D=.79)$ to after the election $(M=$ $.05, S D=.92 ; t(506.09)=1.345, p=0.179)$, but did significantly decrease from before the election to several months after the election $(M=-.40, S D=.79 ; t(450.54)=8.430, p<0.001)$ and from after the election to several months after the election $(t(566.45)=6.806, p<0.001)$. For liberals, threat increased from before $(M=-.12, S D=.88)$ to after the election $(M=.31, S D$ $=.97 ; t(402.46)=-4.686, p<0.001)$ and from before the election to several months after the election $(M=.18, S D=.86 ; t(377.47)=-3.833, p<0.001)$, but did not differ from after the election to several months after the election $(t(413.97)=1.605, p=0.11)$.

\section{The Effects of Threat and Ideology on Conspiracy Endorsement}


We first examined the main effects of threat and ideology on overall conspiracy endorsement. As in Study 1, higher levels of threat $(F(1,548)=46.99, p<0.001)$ and conservatism $(F(1,548)=30.43, p<0.001)$ predicted conspiracy endorsement, and the relationship between ideology and conspiracy endorsement was not moderated by threat $(p=$ 0.979). However, the effect of ideology on conspiracy endorsement was moderated by conspiracy type $(F(2,1106)=526.95, p<0.001)$. Consistent with our expectations, conservative participants were more likely to endorse conservative $(b=0.298, S E=0.014, p<0.001)$ and general $(b=0.042, S E=0.015, p=0.006)$ conspiracies, while liberal participants were more likely to endorse liberal conspiracy theories $(b=-0.154, S E=0.014, p<0.001)$.

\section{Changes in Conspiracy Endorsement over Time}

Next, we examined whether the relationship between threat, participant ideology, and conspiracy endorsement was influenced by the 2016 U.S. Presidential election. In study 2, the four-way interaction of threat, ideology, conspiracy type, and time was not significant $(F(4$, $1106)=1.46, p=0.214$ ). The only significant effect of time in the overall ANOVA model was a main effect of time on endorsement $(F(2,548)=9.39, p<.001)$, where endorsement was the same from before to after the election $(\mathrm{T} 1: M=2.645, S D=0.749, \mathrm{~T} 2: M=2.681, S D=0.751)$ before decreasing months after the election (T3: $M=2.436, S D=0.777)$. While the four-way interaction was not significant, we examined the influence of threat, ideology, and time for each type of conspiracy to see if the effects observed in Study 1 replicated. To do this, we again used OLS regression models.

\{Figure 3 here $\}$

General Conspiracy Endorsement. As in Study 1, threat consistently predicted general conspiracy endorsement $(b=0.197, S E=0.031, p<0.001)$ and this relationship was not 
moderated by time (T1 vs. T2: $b=-0.114, S E=0.082, p=0.168$; T1 vs. T3: $b=0.03, S E=$ $0.082, p=0.711)$ or ideology $(b=0.007, S E=0.016, p=0.630$; see Figure $3 a)$.

Liberal Conspiracy Endorsement. Also consistent with the results from Study 1, threat (b $=0.123, S E=0.028, p<0.001)$ predicted liberal conspiracy endorsement (i.e., conspiracies about conservatives; see Figure $3 b$ ). Overall, ideology did not moderate the effect of threat on endorsement $(b=-0.021, S E=0.014, p=0.14)$, nor did time (T1 vs T2: $b=-0.041, S E=0.073$, $p=0.578$; T1 vs T3: $b=0.074, S E=0.072, p=0.306)$. However, before and after the election both threat $(\mathrm{T} 1: b=0.131, S E=0.054, p=0.017 ; \mathrm{T} 2: b=0.077, S E=0.046, p=0.098)$ and ideology (T1: $b=-0.181, S E=0.025, p=0.001 ; \mathrm{T} 2: b=-0.144, S E=0.026, p<0.001)$ showed main effects on conspiracy endorsement. There was a significant three-way interaction of threat by ideology by time, such that the interaction of ideology and threat differed from before the election to months after the election (T1 vs. T3: $b=-0.077, S E=0.038, p=0.043$ ), but not from before to right after the election (T1 vs. T2: $b=-0.058, S E=0.040, p=0.14$ ). The relationship between threat and conspiracy endorsement was stronger for more liberal participants months after the election (T3: $b=-0.044, S E=0.022, p=0.047)$, but this two-way interaction of threat by ideology was not present before the election (T1: $b=0.028, S E=0.029, p=0.337$ ) or immediately after the election (T2: $b=-0.032, S E=0.024, p=0.193)$. This pattern suggests that the first couple of months after President Trump took office were especially negative for more strongly identified liberals, which resulted in threatened liberals being more likely to endorse conspiracy theories targeting conservatives months after the election compared to before the election and immediately after the election.

Conservative Conspiracy Endorsement. The pattern observed for conservative conspiracy endorsement in Study 2 was largely consistent with that observed in Study 1. Threat predicted 
conservative conspiracy endorsement $(b=0.135, S E=0.029, p<0.001$, see Figure $3 c)$.

Ideology moderated the effect of threat on endorsement $(b=0.027, S E=0.015, p=0.067$, such that more conservative participants showed a stronger relationship between threat and endorsement. The effect of threat on endorsement differed from before to right after the election (T1 vs. T2: $b=-0.188, S E=0.075, p=0.012$ ), but not from before the election to months after the election (T1 vs. T3: $b=-0.071, S E=0.074, p=0.338$ ). Threat predicted endorsement of conservative conspiracies before the election (T1: $b=0.225, S E=0.062, p<0.001)$ but, as expected, this effect was weaker after the election (T2: $b=0.078, S E=0.047, p=0.094$; T3: $b=$ 0.096, $S E=0.05, p=0.057)$. Conservative conspiracy endorsement was a function of threat $(\mathrm{T} 1$ : $b=0.225, S E=0.061, p<0.001)$ and ideology $(\mathrm{T} 1: b=0.026, S E=0.028, p<0.001)$ before the election, but after the election endorsement was explained by only ideology $(\mathrm{T} 2: b=0.313, S E=$ 0.026, $p<0.001$; threat: $b=0.077, S E=0.046, p=0.093)$. However, months after President Trump took office, endorsement of conservative conspiracies was a function of threat (T3: $b=$ $0.161, S E=0.046, p<0.001)$, though weaker than before the election, and ideology $(\mathrm{T} 3: b=$ $0.304, S E=0.022, p<0.001)$. The overall pattern suggests that the decreased impact of threat on endorsement for conservatives after the election was temporary, and threat again had a predictive impact on endorsement after the inauguration, albeit weaker than prior to the election.

\section{Discussion - Studies 1 and 2}

In the first two studies we used the 2016 U.S. Presidential election as a natural experiment to examine the relationship between threat, ideology, and conspiracy endorsement. Consistent with prior research, we found that political threat is a robust predictor of conspiracy endorsement, but we also find evidence that the strength of political identification moderates the impact of threat on endorsement, at least some of the time. While we find evidence across studies 
that ideology moderates the effect of threat on conspiracy endorsement, results differed somewhat across the two samples. In Study 1, ideology appeared to impact the effect of threat on endorsement of general and liberal conspiracy theories, but ideology only moderated the effect of threat on endorsement of conservative conspiracy theories in Study 2. It is not clear why these effects differed across studies, but it is possible that sample demographics (AMT vs. student participants), different timelines for data collection (November-December 2016 vs. November 2016-April 2017), or the quasi-experimental nature of these analyses may have had an impact.

For these reasons, we opted for a third study to examine the causal role of threat and ideology on conspiracy theory endorsement using an experimental design, which is a substantial break from the prior work that has used almost exclusively survey designs (Douglas et al., 2019). Study 3 differed from the two prior studies in three meaningful ways. First, though using a real election may offer a powerful and generalizable manipulation of political threat that could be hard to replicate with a controlled experiment, we chose to use an experimental design in Study 3 that offered more experimental control. While Studies 1 and 2 used non-representative convenience samples, we administered the experiment to a nationally representative sample in Study 3. Finally, since political threat may be more akin to group threat rather than individual threat and political scientists suggest that partisanship is fundamentally a group-based attachment in a way that ideology may not be (Greene, 1999; 2004; Green, Palmquist, \& Schickler, 2002; but see Haas, Jones, \& Fazio, 2019), we shifted from examining the moderating effect of ideology in Studies 1 and 2 to examining the effect of partisanship in Study 3.

\section{Study 3 Methods}

To examine whether political threat has a causal effect on conspiracy endorsement and how the effect of threat is impacted by political identity (i.e., partisanship), we conducted a 
survey experiment that randomly assigned participants to either a political threat or a control condition. Participants were first given the chance to identify as Republican or Democrat and then randomly assigned to condition. In the political threat conditions, individuals read a vignette designed to induce partisan threat specific to their party identity. In the control conditions, participants were either exposed to a message focused on safety/security or a neutral control. Following the vignette, conspiracy theory endorsement was measured. We expected that conspiracy endorsement would be higher in the threat conditions relative to control conditions and that threatened partisans would be especially likely to endorse conspiracy theories about their opposition (i.e., threatened Republicans would endorse more conspiracy theories about Democrats and threatened Democrats would endorse more conspiracy theories about Republicans).

Participants

Participants in Study 3 were a representative sample of Americans recruited online through Dynata between June 26, 2019, and July 9, $2019(N=1,425)$. Participants were compensated by Dynata for their participation. Overall, participants in the third sample were politically moderate (ideology: $1=$ very liberal, $7=$ very conservative, $M=4.183, S D=1.919$ ), middle aged (age: $M=46.14, S D=16.39$ ), evenly split in terms of gender (female: $50 \%$ ), and fairly educated $($ Mode = "Bachelor's degree").

\section{Materials and Procedure}

After consenting to participate in the study, participants were asked whether they considered themselves "a Democrat, a Republican, an Independent, or something else?" Participants who identified as an independent or something else were asked a follow up item that asked them whether they considered themselves "as closer to the Republican Party or the 
Democratic Party.” Based on these initial questions, participants were categorized as Republican or Democrat and were then randomly assigned to one of four conditions based on their party identification. Republicans could be randomly assigned to one of the two control conditions or a Republican threat condition, and Democrats could be randomly assigned to either of the two control conditions or a Democrat threat condition.

In each condition, respondents were tasked with reading a short vignette and were then asked to write a short paragraph describing how they felt about the material presented in the vignette. The vignette in the safety/security control condition told respondents that "many people in the United States feel satisfied with the nation's condition" and that in comparison to other countries the U.S. had "reached a high point in terms of social, economic and political factors." Those in the neutral control condition read a vignette that was void of political references in that it described how many people enjoy watching television. Finally, the vignette provided to those assigned to either the Democrat threat or Republican threat condition stated that "many people in the United States feel disappointed with the nation's condition" and that "many citizens feel that the country has reached a low point in terms of social, economic and political factors." This wording mirrored that used in the safety/security control condition aside from the use of positive or negative adjectives. The only difference between the two threat conditions was in which party was blamed for the United States' decline. In the Democrat threat condition $(n=244)$, Democrats were blamed, while Republicans were blamed in the Republican threat condition $(n=$ 252; full wording is provided in the Appendix). This serves as a manipulation of ingroup party threat, as participants were told their own party is responsible for the decline in American society. Participants in the two control conditions did not differ in their ratings of the three conspiracy endorsement scales ( $p s=0.204$ to 0.346 ), so the two control conditions were 
combined to create a single control condition for analysis $(n=929)$. For analysis, we also collapse the two threat conditions but examine party identification as a moderating variable, so we are examining the impact of both threat and party identification on conspiracy endorsement.

Following the vignette and writing task, all participants completed the same survey. The survey first asked the same two political threat items used in Studies 1 and 2 (i.e., "How threatened do you feel by the government?" and "How threatened do you feel by politicians in government?") using the same five-point response scale as the previous studies. The two political threat items were presented in a randomized order. These two items were strongly correlated $(r=$ $0.79, p<0.001)$, so responses were averaged to create a political threat score $(M=2.652, S D=$ 1.186) that was mean-centered for analysis.

After the two threat items, participants received a 12-item Positive and Negative Affect Schedule (PANAS; adapted from Watson, Clark and Tellegen, 1988) scale and a 5-item political knowledge scale. These items were used as a distractor task with the intention of creating separation between the manipulation and measurement of the dependent variables (i.e., conspiracy theory endorsement items $)^{4}$. Responses from these items were not analyzed.

Participants next completed the same three scales designed to measure conspiracy endorsement used in Studies 1 and 2. Specifically, participants were tasked with evaluating how likely each of the items were to be true (five-point scale: $1=$ Definitely not true, $5=$ Definitely true) for the fifteen-items from the general conspiracy theory scale created by Brotherton and colleagues $(2013 ; \alpha=0.94, M=2.907, S D=0.917)$, the ten items from the liberal conspiracy theory scale $(\alpha=0.88, M=3.066, S D=0.896)$, and the ten items from the conservative

\footnotetext{
${ }^{4}$ Prior research using threat manipulations has found that the effect of the manipulation is stronger following a delay (Haas \& Cunningham, 2014; Pyszcyznski, Greenberg, \& Solomon, 1999).
} 
conspiracy theory scale $(\alpha=0.91, M=2.83, S D=1.012)$. Items from all three conspiracy scales were presented in the same block of items in a randomized order. After the conspiracy items, participants completed a series of demographic and political attitude items before being debriefed.

\section{Study 3 Results and Discussion}

\section{Manipulation Check}

We first examined differences between condition in political threat to test whether the partisan threat manipulation led participants to express higher levels of threat compared to those in the control conditions. Consistent with expectations, political threat was higher in the threat $(M=0.083, S D=1.195)$ compared to control conditions $(M=-0.044, S D=1.179 ; F(1,1383)=$ 4.234, $p=0.0398)$. We also examined whether there were any asymmetries in how well the manipulation worked to threaten Democrats versus Republicans. The condition by party interaction was not significant $(F(1,1383)=0.238, p=0.625)$, which suggests that the threat condition produced feelings of threat for both Democrats and Republicans. However, we did find a main effect of party identification $(F(1,1383)=65.492, p<0.001)$ with Democrats $(M=0.265$, $S D=1.203)$ expressing higher levels of threat overall compared to Republicans $(M=-0.243, S D$ $=1.120)$. One reason for this disparity could be that while Democrats gained a majority of seats in the House of Representatives in the 2018 midterm election, Republicans still held a majority in the Senate and control of the Presidency when data was collected. While baseline threat levels may have differed between Republican versus Democratic participants at the time, we expected to find relative differences in conspiracy endorsement across conditions as a function of the experimental manipulation of political threat.

\section{The Effects of Threat and Party Identification on Conspiracy Endorsement}


Before examining the effect of the threat condition on general and ideological conspiracy theories, we examined the main effects of the threat manipulation and party identification on overall conspiracy endorsement. Consistent with Studies 1 and 2, conspiracy endorsement was higher in the threat condition $(M=2.979, S D=0.025)$ than the control condition $(M=2.918, S D$ $=0.948)$, but not significantly higher $(F(1,1386)=2.229, p=0.136)$. Democrats were also more likely to endorse conspiracy theories $(M=3.005, S D=0.976)$ than Republicans $(M=2.875, S D$ $=0.921 ; F(1,1386)=10.937, p<0.001)$. The relationship between threat and overall conspiracy endorsement did not vary as a function of party identification $(F(1,1386)=0.805, p=0.369)$.

Next, we examined whether the effect of party identification on conspiracy endorsement varied as a function of conspiracy type (i.e., general, liberal, or conservative) and threat condition. There was a significant party identification by conspiracy type interaction $(F(2,2772)$ $=730.513, p<0.001)$, but this interaction was moderated by threat condition $(F(2,2772)=$ $6.771, p<0.001)$, which is discussed in more detail below.

\{Figure 4 here $\}$

\section{Impact of Threat Condition on General Conspiracy Endorsement}

Though we did not have a specific hypothesis as to who would be more likely to endorse general conspiracy theories, we did examine the effect of party identification on general conspiracy endorsement. In study 3, Democrats $(M=3.081, S D=0.868)$ were more likely to endorse general conspiracies than Republicans $(M=2.751, S D=0.932 ; F(1,1386)=45.965, p<$ 0.001). However, the effect of threat condition was not significant $(F(1,1386)=2.027, p=$ $0.155)$ and the effect of party identification was not moderated by threat $(F(1,1386)=0.217, p=$ 0.642), suggesting that the threat manipulation did not influence endorsement of the general conspiracy theories in Study 3. 


\section{Impact of Threat Condition on Endorsement of Conspiracies Targeting Republicans}

Next, we examined the impact of threat and party identification on endorsement of conspiracies that targeted conservatives (i.e., liberal conspiracy theories). Liberal conspiracy theory endorsement differed as a function of threat condition $(F(1,1386)=4.530, p=0.033)$ and party identification $(F(1,1386)=433.488, p<0.001)$ but the effect of threat condition was not moderated by party identification $(F(1,1386)=0.968, p=0.325)$. Democrats $(M=3.528, S D=$ 0.690) endorsed liberal conspiracy theories more than Republicans $(M=2.649, S D=0.864)$, suggesting that the liberal conspiracy scale worked as intended (see Figure 4a). Political threat increased liberal conspiracy endorsement with those in the threat condition $(M=3.112, S D=$ 0.887) showing higher levels of endorsement than those in the control condition $(M=3.042, S D$ $=0.901)$. However, the impact of threat did not differ by party identification, so we do not replicate the finding from Study 1 where the effect of threat on endorsement was dependent on political identity, rather both of these factors independently predicted endorsement.

\section{Impact of Threat Condition on Endorsement of Conspiracies Targeting Democrats}

Next, we examined the impact of threat and party identification on endorsement of conspiracies that targeted liberals (i.e., conservative conspiracy endorsement). As expected, there was a main effect of party identification on endorsement such that Republicans $(M=3.226, S D=$ 0.862) were more likely to endorse conservative conspiracies than Democrats $(M=2.408, S D=$ $0.998 ; F(1,1386)=269.621, p<0.001)$. The main effect of threat condition on endorsement was not significant $(F(1,1386)=0.102, p=0.749)$, but the main effect of party was moderated by threat $(F(1,1386)=6.162, p=0.013)$. Threat increased endorsement for Republicans but not for

Democrats (see Figure 4b). Republicans in the threat condition showed higher endorsement $(M=$ $3.38, S D=0.783)$ than Republicans in the control condition $(M=3.173, S D=0.894 ; t(513.42)=$ 
$-2.509, p=0.012)$. For Democrats, there was no difference between the threat condition $(M=$ $2.343, S D=1.029)$ and the control condition $(M=2.442, S D=0.979)$ in terms of endorsement of conservative conspiracies $(t(444.6)=1.195, p=0.233)$. These findings are consistent with the effect we found in Study 2, where political identity moderated the impact of threat on conservative endorsement of conspiracies targeting liberals.

\section{Study 3 Discussion}

The results of Study 3 corroborate the results of the Studies 1 and 2 in that political threat provides a powerful motivation to endorse conspiracy theories. Political threat led to higher endorsement of both liberal and conservative conspiracy theories, although we find some evidence for an asymmetry here in the mechanism by which this impact takes place. For Democrats, endorsement was a function of threat and partisanship, although these effects were independent. For Republicans, endorsement was a function of both threat and partisanship, but partisanship enhanced the impact of threat in that threat only increased endorsement of conspiracies targeting liberals for Republicans and not for Democrats. The nature of the interaction between threat and partisanship (or political identity) differed in Study 3 compared to Studies 1 and 2, which may suggest that the way in which threat impacts conspiracy endorsement is dependent on political context. Though the experiment implemented in Study 3 sought to provide us with more control than offered by the natural experiment used in Studies 1 and 2, the results suggest that experimentally manipulating political threat might interact with pre-existing levels of emotion, like in-group pride, from having one's political party in power.

\section{General Discussion}

Across three studies, we found both observational and causal evidence for the idea that political threat predicts conspiracy endorsement and consistent evidence for the idea that 
endorsement is tied to group membership, such that liberals (Democrats) are more likely to endorse conspiracies targeting conservatives (Republicans) and vice versa. Interestingly, we find that the moderating influence of identity on the relationship between threat and endorsement fluctuates between studies. In Study 1, threat had a larger impact on endorsement of conspiracies targeting conservatives for liberal participants, whereas in Studies 2 and 3 threat had a larger impact on endorsement of conspiracies targeting liberals for conservative/Republican participants. Thus, sometimes threat increases motivated reasoning for liberal/Democrat participants and other times for conservative/Republican participants.

Rather, the impact of threat and ideology seems to be context-dependent, shifting over time as a function of proximity to the 2016 U.S. Presidential election and election outcome in Studies 1 and 2. As for the shifting effect of threat and ideology before and after the 2016 U.S. Presidential election, the results from Study 1 and 2 suggest that the overall effects of threat and ideology on endorsement of general conspiracies did not change much over time- - threat predicts endorsement. Threat and political ideology (being liberal) were also reliable predictors of endorsement of conspiracies targeting conservatives, although the interaction of threat and ideology did fluctuate over time. Importantly, we find that the effect of threat on endorsement of conspiracies targeting liberals shifted dramatically from before to after the election. Prior to the election, both ideology (conservatism) and threat predicted endorsement, whereas after the election endorsement was primarily a function of ideology. In other words, we find that threat no longer predicted endorsement of conservative conspiracies once Donald Trump was elected in 2016. It is not the case that endorsement dropped off entirely, rather, endorsement became a function of group membership rather than emotion. However, data from Study 2 suggests that the 
impact of threat on conservative conspiracy theory endorsement may have started to reappear by early 2017.

In Study 3, we found causal evidence supporting the hypothesis that political threat increases conspiracy endorsement. Individuals were more likely to endorse conspiracy theories when their political party was blamed for the deteriorating state of the country. Regarding partisanship, Democrats and Republicans were more likely to endorse conspiracy theories about their political outgroup when their own party was blamed. However, how threat influenced the endorsement of conspiracies targeting liberals and conservatives did differ in that threat increased the endorsement of conspiracy theories targeting conservatives for both Republicans and Democrats while threat only increased the endorsement of conspiracy theories targeting liberals for Republicans, but not for Democrats. This difference in how threat influenced the endorsement of liberal and conservative conspiracy theories could be due to differences in baseline levels of emotion from the political context at the time (i.e., security or fear arising from the number of seats one's party holds in the Senate or House).

While we find that political threat impacts the endorsement of political conspiracy theories, which is consistent with Uscinski and Parent's (2014) assertion that “conspiracy theories are for losers" (130), we also find mixed support for the idea that conservatives are more likely to endorse conspiracy theories than liberals (see Hofstadter, 1964). Conservatives in Study 1 and 2 were more likely to endorse conspiracy theories, overall, and were also more likely to endorse general conspiracy theories. However, evidence from Study 3 contradicts this assertion with Democrats being more likely than Republicans to endorse conspiracy theories. The inconsistent pattern across studies suggests that political context and sample demographics may be important for understanding the relationship between political leanings and conspiracy 
endorsement. In Studies 1 and 2, conservative participants continued to endorse conspiracies about liberals even after winning the 2016 U.S. Presidential election. In Study 3, Republicans in the threat condition and the control condition endorsed conservative conspiracy theories more than Democrats in either condition. These findings may be the result of the unique circumstances surrounding the 2016 U.S. Presidential election and populist rhetoric common among conservative Republicans and increasingly among liberal progressive Democrats. Populists often portray their opponents as corrupt elites who work secretly work against "the people" (Mudde, 2007), which is not too far from the definition of a conspiracy theory and indeed, some prior research has shown that people who are attracted to populist rhetoric may be more likely to endorse conspiracy theories (Castanho Silva, Vegetti, \& Littvay, 2017). It is feasible that the emergence of populist rhetoric on both the political left and right is drive conspiracy endorsement, given both may be tied to perceptions of threat from a powerful political outgroup. Future work should examine whether populism is driving the endorsement of conspiracy theories and whether emotion and political identity are possible mechanism by which populism and conspiracy are related (see Haas, 2020).

Collectively, the results provide support for our primary hypotheses regarding the effects of threat and ideology on conspiracy endorsement, but we find these effects can shift over time as a function of election outcomes and the balance of power in the two-party system. Importantly, liberals can be as likely or more likely than conservatives to endorse conspiracy theories depending on the type of conspiracy theory and how threatened they feel. This work is consistent with the view that when individuals are politically threatened, they are more likely to endorse political conspiracies targeting their opponents. This is a cause for concern, especially in a time of increased polarization in American politics. The rise of partisan politics may contribute to 
POLITICAL THREAT AND CONSPIRACY ENDORSEMENT 26

increased perceptions of political threat, which is likely to contribute to increased spread of misinformation. Contrary to prior work arguing conspiracies are primarily a conservative phenomenon, no political group is immune to conspiratorial thinking when threatened. 


\section{References}

Abalakina-Paap, M., Stephan, W. G., Craig, T., \& Gregory, W. L. (1999). Beliefs in conspiracies. Political Psychology, 20(3), 637-647.

Berinsky, A.J., Huber, G.A., \& Lenz, G.S. (2012). Evaluating online labor markets for experimental research: Amazon.com's Mechanical Turk. Political Analysis, 20(3), 351-368.

Bolsen, T., Druckman, J. N., \& Cook, F. L. (2014). The influence of partisan motivated reasoning on public opinion. Political Behavior, 36(2), 235-262.

Brotherton, R., French, C.C., \& Pickering, A.D. (2013). Measuring belief in conspiracy theories: The generic conspiracist beliefs scale. Frontiers in Psychology, 4.

Castanho Silva, B., Vegetti, F., \& Littvay, L. (2017). The Elite Is Up to Something: Exploring the Relation Between Populism and Belief in Conspiracy Theories. Swiss Political Science Review, 23(4), 423-443. doi: 10.1111/spsr.12270

Cohen, J., Cohen, P., West, S.G., \& Aiken, L.S. (2003). Applied multiple regression/correlation analysis for the behavioral sciences. Mahwah, NJ: Lawrence Erlbaum Associates.

Douglas, K. M., Sutton, R. M., \& Cichocka, A. (2017). The psychology of conspiracy theories. Current Directions in Psychological Science, 26(6), 538-542.

Douglas, K. M., Uscinski, J. E., Sutton, R. M., Cichocka, A., Nefes, T., Ang, C. S., \& Deravi, F. (2019). Understanding conspiracy theories. Political Psychology, 40, 3-35.

Edelson, J., Alduncin, A., Krewson, C., Sieja, J. A., \& Uscinski, J. E. (2017). The effect of conspiratorial thinking and motivated reasoning on belief in election fraud. Political Research Quarterly, 70(4), 933-946. 
Flynn, D.J., Nyhan, B., \& Reifler, J. (2017). The nature and origins of misperceptions: understanding false and unsupported beliefs about politics. Advances in Political Psychology, $38,127-150$.

Ghaffary, S. (2020, November 02). The long-term consequences of Trump's conspiracy theory campaign. Vox. https://www.vox.com/recode/21546119/trump-conspiracy-theories-election2020-coronavirus-voting-vote-by-mail

Green, D.P., Palmquist, B., \& Schickler, E. (2002). Partisan hearts and minds: Political parties and the social identities of voters. New Haven: Yale University Press.

Greene, S. (1999). Understanding party identification: A social identity approach. Political Psychology, 20(2), 393-403.

Greene, S. (2004). Social identity theory and party identification. Social Science Quarterly, 85(1), 136-153.

Guess, A., Nyhan, B., \& Reifler, J. (2018). Selective exposure to disinformation: Evidence from the consumption of fake news during the 2016 US presidential campaign. European Research Council, 9, 1-14.

Haas, I. J. (2020). Using political psychology to understand populism, intellectual virtues, and democratic backsliding. PsyArXiv, doi: https://doi.org/10.31234/osf.io/8j69g

Haas, I.J., \& Cunningham, W.A. (2014). The uncertainty paradox: Perceived threat moderates the effect of uncertainty on political tolerance. Political Psychology, 35(2), 291-302.

Haas, I. J., Jones, C. R., \& Fazio, R. H. (2019). Social identity and the use of ideological categorization in political evaluation. Journal of Social and Political Psychology, 7(1), 335353. doi: 10.5964/jspp.v7i1.790 
Hetherington, M., \& Suhay, E. (2011). Authoritarianism, threat, and Americans' support for the war on terror. American Journal of Political Science, 55(3), 546-560.

Hofstadter, R. (1964). The paranoid style in American politics. Harper's Magazine, 229(1374), $77-86$.

Hopp, T., \& Vargo, C. J. (2019). Social capital as an inhibitor of online political incivility: An analysis of behavioral patterns among politically active Facebook users. International Journal of Communication, 13, 21.

Katz, J. (2016, July 19). 2016 Election Forecast: Who Will Be President? The New York Times. https://www.nytimes.com/interactive/2016/upshot/presidential-polls-forecast.html

Kunda, Z. (1990). The case for motivated reasoning. Psychological Bulletin, 108(3), 480-498.

Levay, K.E., Freese, J., \& Druckman, J.N. (2016). The demographic and political composition of Mechanical Turk samples. Sage Open, 6(1), 1-17

Lodge, M., \& Taber, C.S. (2013). The rationalizing voter. Cambridge, UK: Cambridge University Press.

Marchlewska, M., Cichocka, A., \& Kossowska, M. (2018). Addicted to answers: Need for cognitive closure and the endorsement of conspiracy beliefs. European Journal of Social Psychology, 48(2), 109-117.

Miller, J.M., Saunders, K.L., \& Farhart, C.E. (2015). Conspiracy endorsement as motivated reasoning: The moderating roles of political knowledge and trust. American Journal of Political Science, 60(4), 824-844.

Mudde, C. (2007). Populist radical right parties in Europe. Cambridge: Cambridge University Press. 
Nyhan, B. (2014, August 25). Fighting Ebola, and the conspiracy theories. The New York Times. https://www.nytimes.com/2014/08/26/upshot/fighting-ebola-and-the-conspiracy$\underline{\text { theories.html? } \mathrm{r}=1}$

Oliver, E.J., \& Wood, T. (2014). Conspiracy theories and the paranoid style(s) of mass opinion. American Journal of Political Science, 58(4), 952-966.

Pasek, J., Stark, T.H., Krosnick, J.A., \& Tompson, T. (2015). What motivates a conspiracy theory? Birther beliefs, partisanship, liberal-conservative ideology, and anti-black attitudes. Electoral Studies, 40, 482-489.

Pyszczynski, T., Greenberg, J., \& Solomon, S. (1999). A dual-process model of defense against conscious and unconscious death-related thoughts: an extension of terror management theory. Psychological Review, 106(4), 835.

Taber, C.S., \& Lodge, M. (2006). Motivated skepticism in the evaluation of political beliefs. American Journal of Political Science, 50(3), 755-769.

See, Y.H., \& Petty, R.E. (2006). Effects of mortality salience on evaluation of ingroup and outgroup sources: The impact of pro- versus counterattitudinal positions. Personality and Social Psychology Bulletin, 32(3), 405-416.

Silver, N. (2016, November 08). 2016 Election Forecast. Five Thirty Eight. https://projects.fivethirtyeight.com/2016-election-forecast/

Swami, V. (2012). Social psychological origins of conspiracy theories: The case of Jewish conspiracy theory in Malaysia. Frontiers in Psychology, 3.

Sullivan, D., Landau, M. J., \& Rothschild, Z. K. (2010). An existential function of enemyship: Evidence that people attribute influence to personal and political enemies to compensate for threats to control. Journal of Personality and Social Psychology, 98(3), 434-449. 
Uscinksi, J.E. (2016, August 22). The 5 most dangerous conspiracy theories of 2016. Politico Magazine. http://www.politico.com/magazine/story/2016/08/conspiracy-theories-2016donald-trump-hillary-clinton-214183

Uscinksi, J.E., \& Parent, J.M. (2014). American conspiracy theories. New York, NY: Oxford University Press.

Van Prooijen, J., \& Acker, M. (2015). The influence of control on belief in conspiracy theories: Conceptual and applied extensions. Applied Cognitive Psychology, 29(5), 753-761.

Van Prooijen, J. W., Krouwel, A. P., \& Pollet, T. V. (2015). Political extremism predicts belief in conspiracy theories. Social Psychological and Personality Science, 6(5), 570-578.

Watson, D., Clark, L.A., \& Tellegen, A. (1998). Development and validation of brief measures of positive and negative affect: the PANAS scales. Journal of Personality and Social Psychology, 54(6), 1063-1070.

Wood, M.J., Douglas, K.M., \& Sutton, R.M. (2012). Dead and alive: Beliefs in contradictory conspiracy theories. Social Psychological and Personality Science, 3(6), 767-773. 
Figure 1. Timeline comparison of time between Study 1 and Study $2(T=$ time).

Study 1 and 2 Timelines

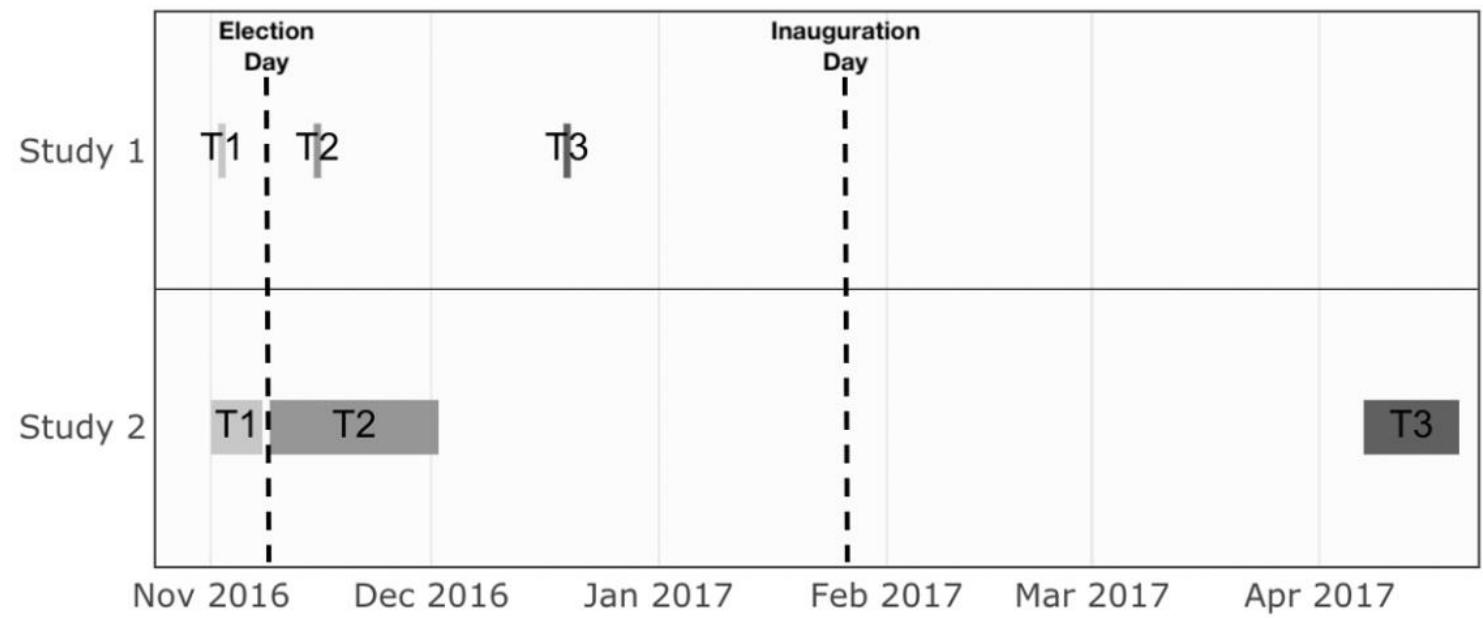

Nov 2016 Dec 2016 Jan 2017 Feb 2017 Mar 2017 Apr 2017 
Figure 2a-c. Conspiracy endorsement as a function of threat, participant ideology (conservative, liberal), conspiracy type (General, Liberal, Conservative), and time (1, 2,3). For ease of interpretation, ideology was dichotomized for plotting (but treated as continuous in statistical models). Higher values on the $y$ axis indicate greater conspiracy endorsement and higher values on the $\mathrm{x}$ axis indicate greater threat.

Figure 2a
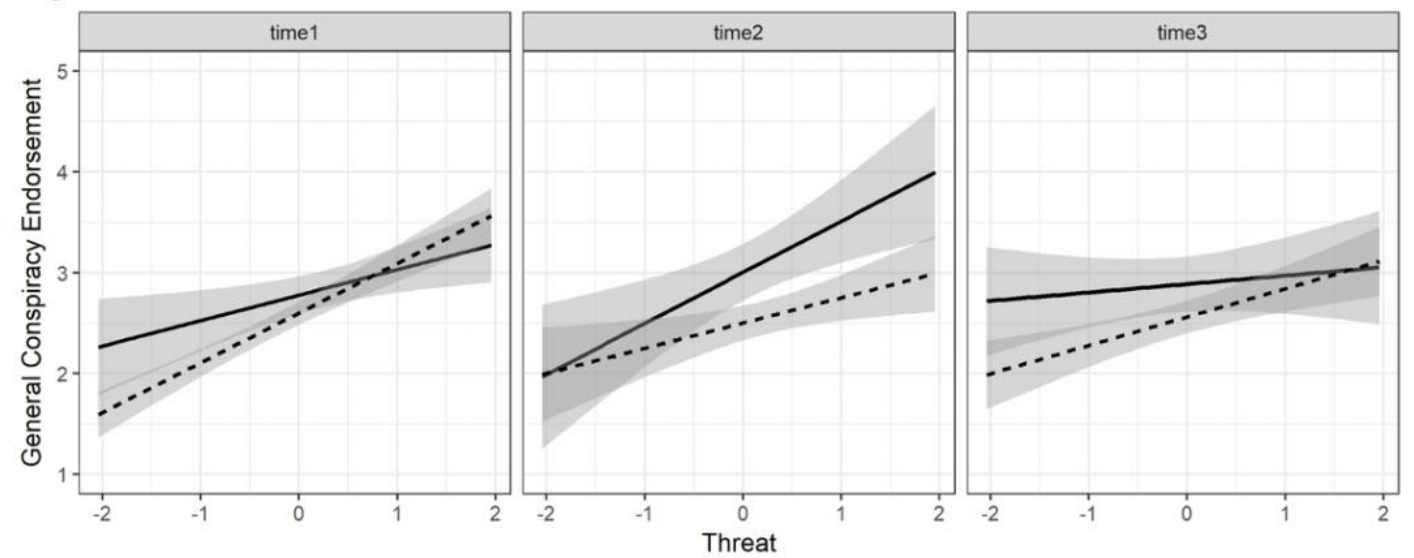

Participant ID

- conservative

- - liberal

Figure 2b
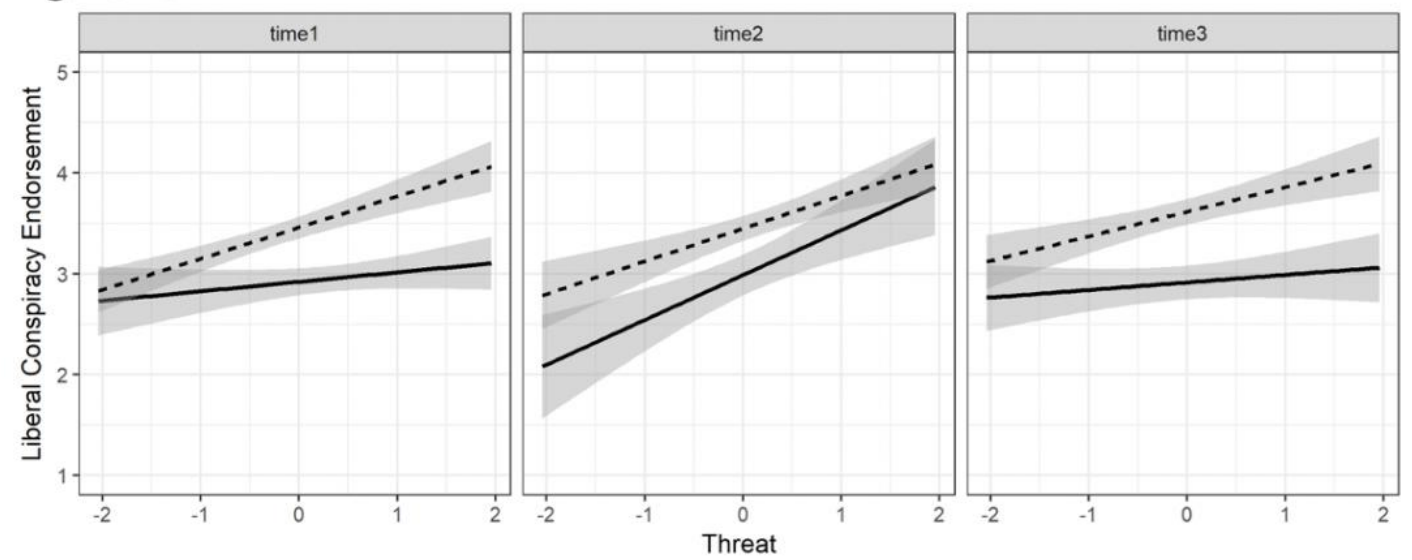

Participant ID

- conservative

-- liberal

Figure 2c
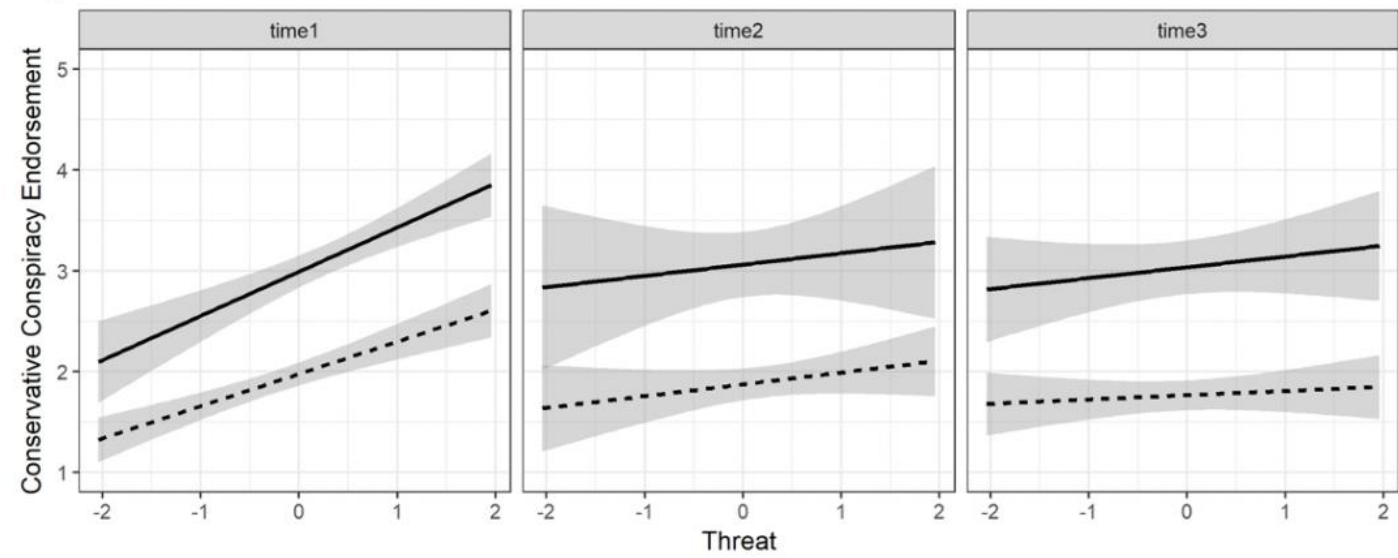

Participant ID

- conservative

- - liberal 
Figure 3a-c. Conspiracy endorsement as a function of threat, participant ideology (conservative, liberal), conspiracy type (General, Liberal, Conservative), and time (1, 2, 3). For ease of interpretation, ideology was dichotomized for plotting (but treated as continuous in statistical models). Higher values on the y axis indicate greater conspiracy endorsement and higher values on the $\mathrm{x}$ axis indicate greater threat.

Figure 3a
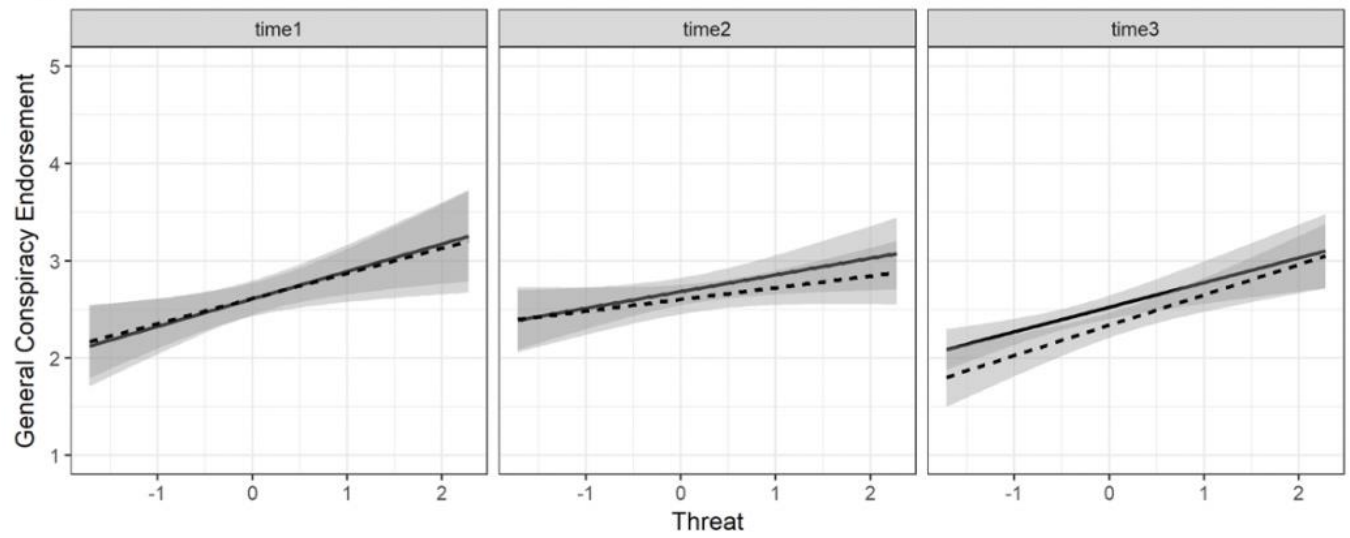

Participant ID

- conservative

- - liberal

Figure 3b
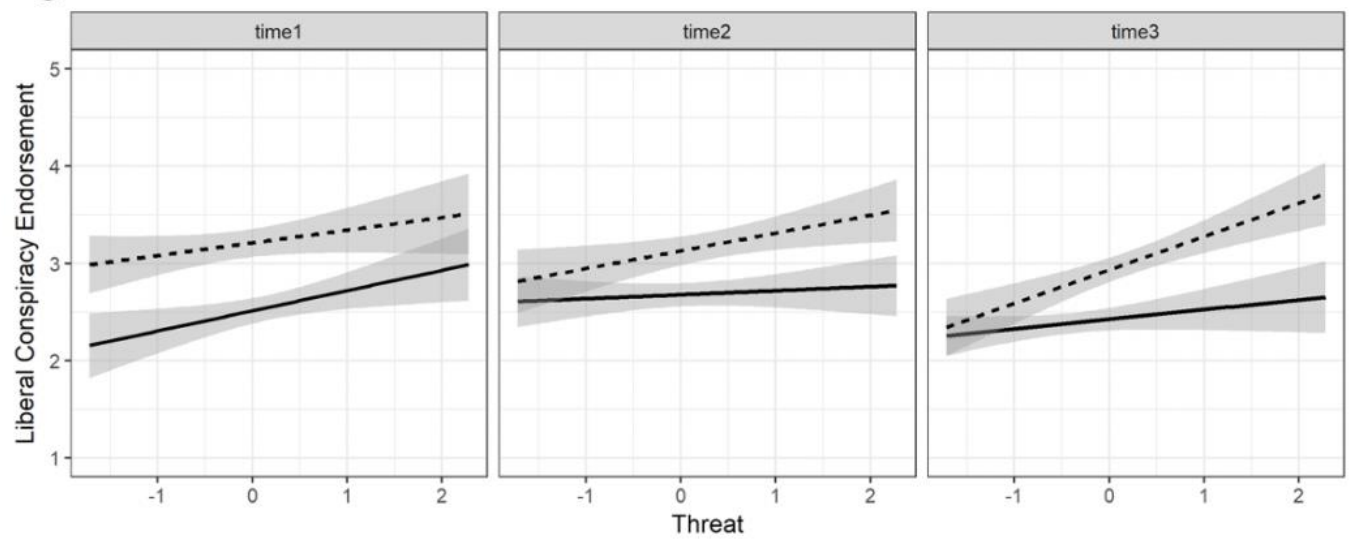

Participant ID

- conservative

-- liberal

Figure 3c
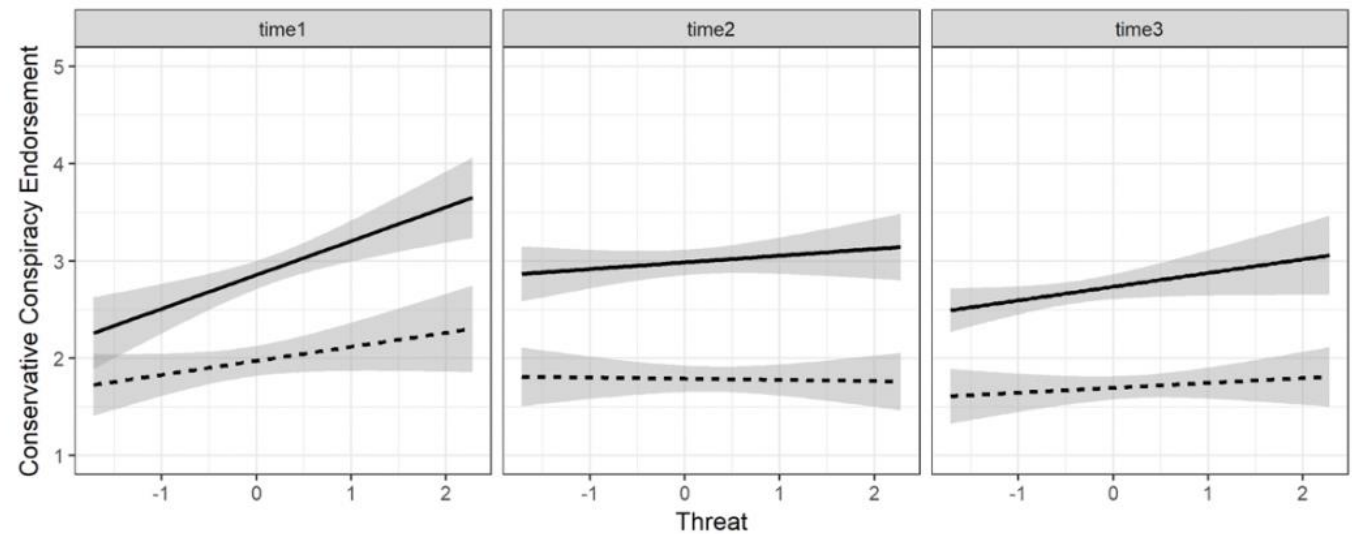

Participant ID

- conservative

- - liberal 
Figure 4a-4b: Conspiracy endorsement as a function of condition and party identification.

Figure 4a

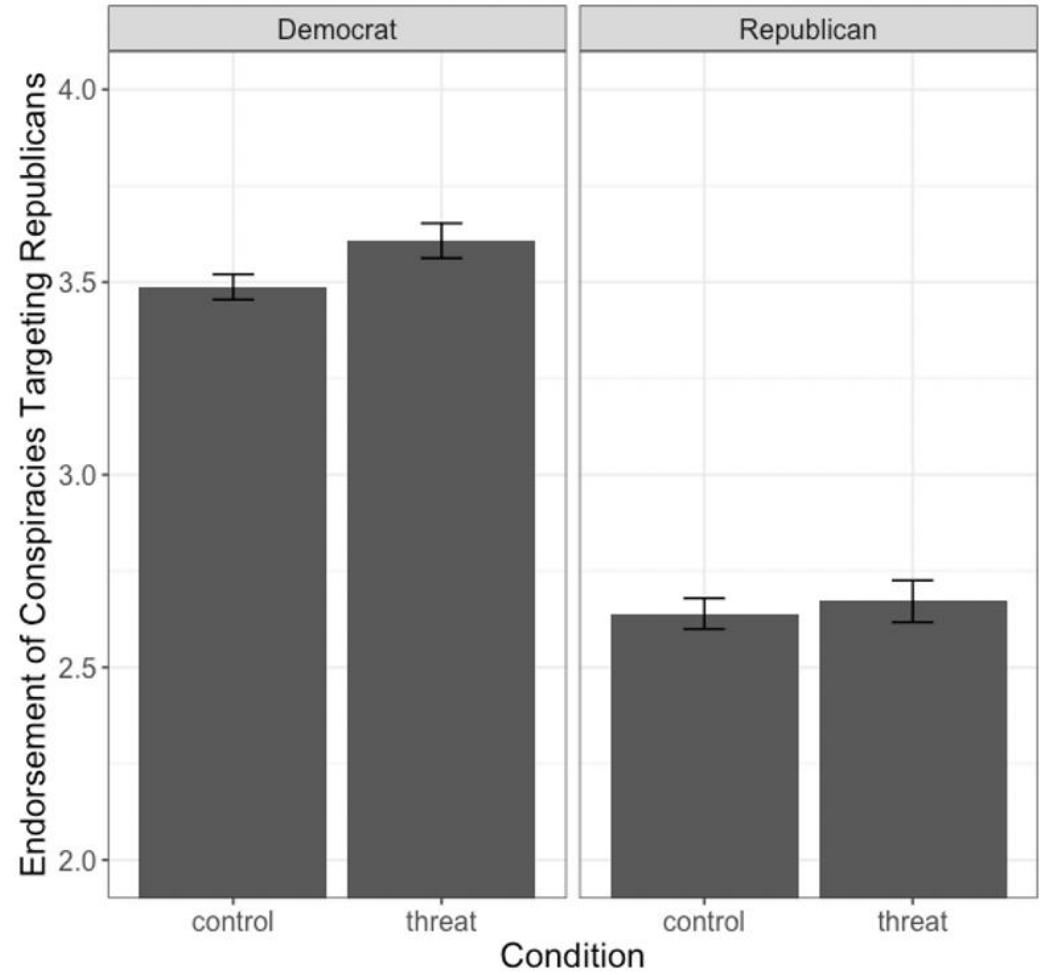

Figure 4b

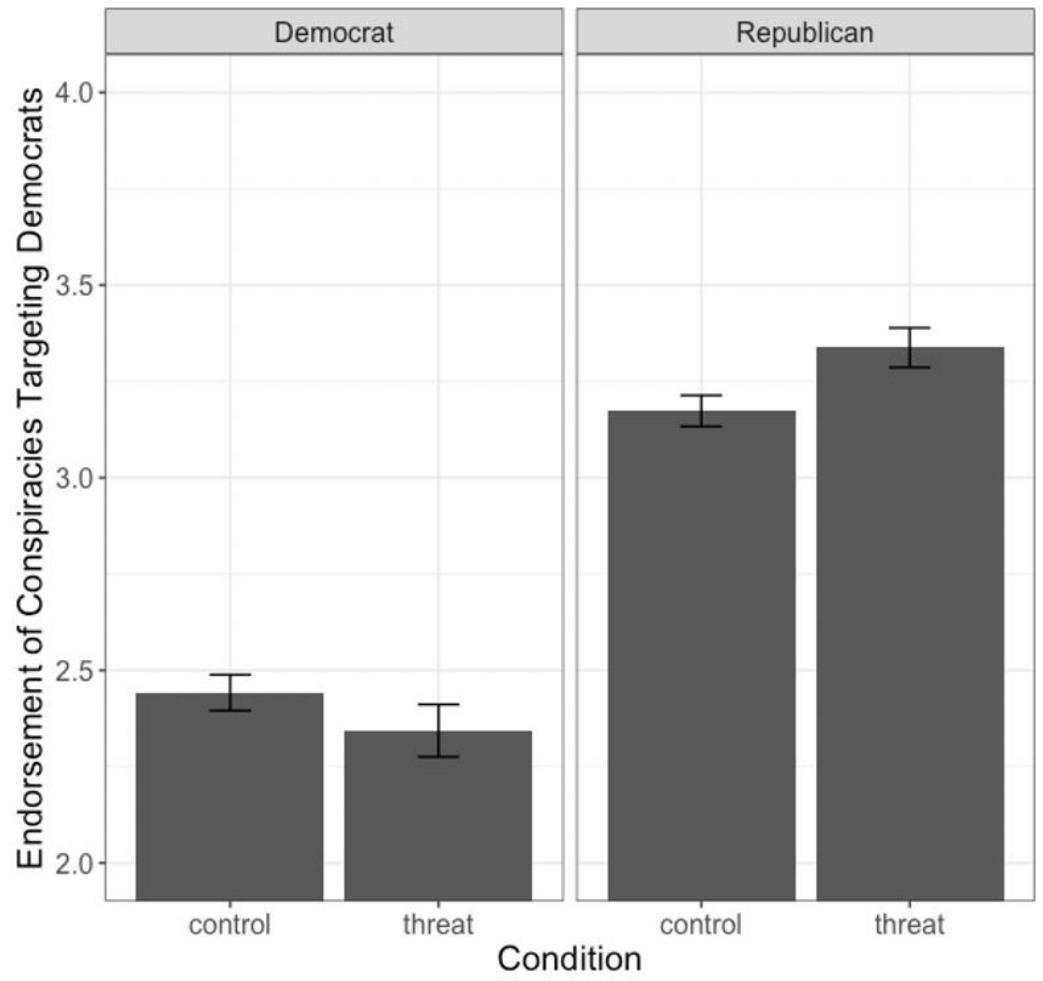




\section{Appendix}

\section{A1: Conspiracy Scale Construction}

To create the equivalent ideological scales, we first generated a list of sixty conspiracy theories, 30 for liberals and 30 for conservatives, we thought either a conservative or liberal would believe. Next, we pilot tested the items with the goal of creating subsets of the two scales that were equally believable. In other words, we tried to develop lists where liberals should be just as likely to endorse the liberal conspiracy theories as conservatives are to endorse the conservative conspiracy theories. A pilot sample was collected from Prolific Academic $(n=166)$ between October 14-16, 2016. Participants in the pilot study rated a random subset of twenty conspiracies using two criteria: which political ideology was most likely to believe the conspiracy (seven-point scale ranging from $1=$ liberal to $7=$ conservative with "neither" as a midpoint), and how believable the conspiracy was (seven-point scale: 1 = Extremely believable, $4=$ Neither believable nor unbelievable, and $7=$ Extremely unbelievable). We first used the ideological rating to discriminate between liberal and conservative conspiracies and then used the believability rating to create two lists, one liberal and the other conservative, each with ten conspiracies that were roughly balanced on mean levels of believability (scale believability means: liberal $=4.10$, conservative $=4.12)$. Like the Generic Conspiracist Belief Scale $(\mathrm{GCB}$; Brotherton, French, and Pickering 2013), the two ideological conspiracy scales were reliable across the three MTurk samples (Cronbach's alpha: liberal scale $=0.80$, conservative scale $=$ 0.90). Responses on each of these scales were combined for analysis. 


\section{A2: Liberal Conspiracy Items and Ratings}

\section{Conspiracy}

$\underline{\text { Ideology }}$

of

$\underline{\text { Believer }}$

Mean

The Republican Party knows its economic policies will hurt average Americans but uses social issues like abortion and same-sex marriage to get low income

1 Americans to vote against their economic interest.

2

Mass incarceration of Black men is a modern day form of slavery.

2.547

1.682

4.038

2.047

George W. Bush lied about the reasons for invading Iraq 3 as he was only interested in taking Iraqi oil.

Congress favors Wall Street over Main Street and passed

4 laws that make it very difficult for CEOs to serve prison time.

Police regularly plant drugs and guns on people they shoot in order to cover up police wrongdoing.

The two major parties are cooperating with rich people and corporations and suppressing the views of average

6 Americans.

1.613

2.804

Donald Trump is deliberately hiding how much he is

7 really worth because he is significantly less wealthy than he claims to be.

2.851

1.197

2.83

The War on Drugs was declared in order to destroy the political power of minority communities.

Billionaires like the Koch brothers make campaign donations to members of Congress in exchange for votes on key pieces of legislation that helps their businesses.

Big banks allowed the financial collapse of 2008 to occur so that they could make bigger profits off of home foreclosures. 


\section{A3: Conservative Conspiracy Items and Ratings}

$\underline{\text { Conspiracy }}$ $\underline{\text { Ideology }}$

of

$\underline{\text { Believer }}$

Mean

FEMA is secretly building concentration camps to

imprison people who speak out against the government.

While Hillary Clinton was Secretary of State she

2

embezzled \$50 billion from the State Department

Democrats are allowing undocumented immigrants to

3

vote so that Hillary Clinton wins the presidency.

The media is run by groups which want to only present a

4 liberal view of the world.

The United Nations is asking the United States to take in

5 Syrian refugees as a plot to destabilize the security of the United States

Common Core is part of a socialist agenda to control

6 young minds.

Muslims are using democratic processes in the United

7 States to implement Sharia Law, which legalizes domestic abuse of women.

The wage gap between males and females is non-existent, but liberal groups claim there is a wage gap in order to

$8 \quad$ keep people divided.

Political forces are rigging the 2016 election by

9 destroying ballots cast for Donald Trump so that Hillary Clinton becomes president.

The media is helping to elect Hillary Clinton by refusing

10
5.492

1.917

4.839

1.977

5.63

1.691

4.348

5.475

1.675

4.237

1.86

5.867

1.241

5.433

1.863

5.132

1.665

5.057

6.096

1.272

5.519

5.109

1.741

4.978

1.807

5

1.673

3.179

2.081 


\section{A4: Measurement of Political Threat}

1. How threatened do you feel by the government?

Very unthreatened

Unthreatened

Neither unthreatened or threatened

Threatened

Very threatened

2. How threatened do you feel by politicians in government?

Very unthreatened

Unthreatened

Neither unthreatened or threatened

Threatened

Very threatened 


\section{A5: Study 1 Descriptive Statistics (Time 1, Time 2, Time 3)}

Table 1: Study 1, Time 1 Descriptive Statistics

\begin{tabular}{lccccc}
\hline \hline Statistic & $\mathrm{N}$ & Mean & St. Dev. & Min & Max \\
\hline General Conspiracy Endorsement & 315 & 2.679 & 0.915 & 1.000 & 4.933 \\
Liberal Conspiracy Endorsement & 315 & 3.243 & 0.724 & 1.364 & 5.000 \\
Conservative Conspiracy Endorsement & 315 & 2.412 & 0.986 & 1.000 & 5.000 \\
Threat & 315 & 3.011 & 1.027 & 1.000 & 5.000 \\
Ideology & 315 & 3.489 & 1.780 & 1 & 7 \\
Income & 315 & 5.079 & 2.924 & 1 & 14 \\
Age & 315 & 34.197 & 9.978 & 19 & 74 \\
White & 315 & 0.787 & 0.410 & 0 & 1 \\
Education & 315 & 4.044 & 1.451 & 1 & 8 \\
Female & 315 & 0.419 & 0.494 & 0 & 1 \\
\hline
\end{tabular}

Table 2: Study 1, Time 2 Descriptive Statistics

\begin{tabular}{lccccc}
\hline \hline Statistic & $\mathrm{N}$ & Mean & St. Dev. & Min & Max \\
\hline General Conspiracy Endorsement & 164 & 2.672 & 0.871 & 1.000 & 4.467 \\
Liberal Conspiracy Endorsement & 164 & 3.362 & 0.707 & 1.182 & 5.000 \\
Conservative Conspiracy Endorsement & 164 & 2.207 & 0.915 & 1.000 & 4.800 \\
Threat & 164 & 3.122 & 0.892 & 1.000 & 5.000 \\
Ideology & 164 & 2.963 & 1.609 & 1 & 7 \\
Income & 164 & 5.476 & 2.946 & 1 & 14 \\
Age & 164 & 33.646 & 9.036 & 19 & 70 \\
White & 164 & 0.744 & 0.438 & 0 & 1 \\
Education & 164 & 4.024 & 1.490 & 1 & 8 \\
Female & 164 & 0.390 & 0.489 & 0 & 1 \\
\hline
\end{tabular}

Table 3: Study 1, Time 3 Descriptive Statistics

\begin{tabular}{lccccc}
\hline \hline Statistic & $\mathrm{N}$ & Mean & St. Dev. & Min & Max \\
\hline General Conspiracy Endorsement & 125 & 2.767 & 0.824 & 1.000 & 4.733 \\
Liberal Conspiracy Endorsement & 125 & 3.416 & 0.648 & 1.545 & 4.727 \\
Conservative Conspiracy Endorsement & 125 & 2.263 & 0.900 & 1.000 & 4.100 \\
Threat & 125 & 3.064 & 1.092 & 1.000 & 5.000 \\
Ideology & 125 & 3.352 & 1.657 & 1 & 7 \\
Income & 125 & 5.168 & 2.761 & 1 & 13 \\
Age & 125 & 33.528 & 9.203 & 21 & 58 \\
White & 125 & 0.808 & 0.395 & 0 & 1 \\
Education & 125 & 4.216 & 1.604 & 2 & 8 \\
Female & 125 & 0.424 & 0.496 & 0 & 1 \\
\hline
\end{tabular}




\section{A6: Study 1 Statistical Models}

Table 4: Study 1, Mixed Effects ANOVA

\begin{tabular}{|c|c|c|c|c|c|}
\hline & $D f$ & Sum Sq & Mean Sq & $\mathrm{F}$ value & $\operatorname{Pr}(>\mathrm{F})$ \\
\hline \multicolumn{6}{|l|}{ Between Subjects } \\
\hline Threat & 1 & 118.82 & 118.82 & 125.41 & $0.000^{* * *}$ \\
\hline Ideology & 1 & 45.89 & 45.89 & 48.43 & $0.000^{* * *}$ \\
\hline Time & 2 & 0.27 & 0.14 & 0.14 & 0.866 \\
\hline Age & 1 & 8.15 & 8.15 & 8.60 & $0.004^{* * *}$ \\
\hline Education & 1 & 6.67 & 6.67 & 7.04 & $0.008^{* * *}$ \\
\hline Female & 1 & 0.79 & 0.79 & 0.83 & 0.363 \\
\hline White & 1 & 8.79 & 8.79 & 9.28 & $0.002^{* * *}$ \\
\hline Income & 1 & 0.11 & 0.11 & 0.11 & 0.736 \\
\hline Threat X Ideology & 1 & 1.14 & 1.14 & 1.20 & 0.274 \\
\hline Threat X Time & 2 & 6.19 & 3.10 & 3.27 & $0.039^{* *}$ \\
\hline Ideology X Time & 2 & 2.52 & 1.26 & 1.33 & 0.266 \\
\hline Threat X Ideology X Time & 2 & 3.56 & 1.78 & 1.88 & 0.154 \\
\hline Residuals & 482 & 456.68 & 0.95 & & \\
\hline \multicolumn{6}{|l|}{ Within Subjects } \\
\hline Conspiracy Type & 2 & 289.46 & 144.73 & 611.35 & $0.000^{* * *}$ \\
\hline Threat X Conspiracy Type & 2 & 3.79 & 1.89 & 8.00 & $0.000^{* * *}$ \\
\hline Ideology X Conspiracy Type & 2 & 189.37 & 94.68 & 399.96 & $0.000^{* * *}$ \\
\hline Time X Conspiracy Type & 4 & 2.26 & 0.57 & 2.39 & $0.049^{* *}$ \\
\hline Threat X Ideology X Conspiracy Type & 2 & 2.35 & 1.18 & 4.96 & $0.007^{* * *}$ \\
\hline Threat X Time X Conspiracy Type & 4 & 2.47 & 0.62 & 2.61 & $0.034^{* *}$ \\
\hline Ideology X Time X Conspiracy Type & 4 & 2.42 & 0.61 & 2.56 & $0.037^{* *}$ \\
\hline Threat X Ideology X Time X Conspiracy Type & 4 & 2.87 & 0.72 & 3.03 & $0.017^{* *}$ \\
\hline Residuals & 974 & 230.58 & 0.24 & & \\
\hline
\end{tabular}


Table 5: Study 1, OLS Regression Results Predicting General Conspiracy Endorsement

\begin{tabular}{|c|c|c|c|}
\hline \multirow[b]{3}{*}{ Income } & \multicolumn{3}{|c|}{ Dependent variable: } \\
\hline & \multicolumn{3}{|c|}{ General Conspiracy Endorsement } \\
\hline & $\begin{array}{c}0.007 \\
(0.012)\end{array}$ & $\begin{array}{c}0.006 \\
(0.012)\end{array}$ & $\begin{array}{c}0.003 \\
(0.012)\end{array}$ \\
\hline Age & $\begin{array}{c}-0.008^{+4} \\
(0.003)\end{array}$ & $\begin{array}{c}-0.008^{+*} \\
(0.003)\end{array}$ & $\begin{array}{c}-0.008^{*+} \\
(0.003)\end{array}$ \\
\hline White & $\begin{array}{c}-0.211^{*+*} \\
(0.078)\end{array}$ & $\begin{array}{c}-0.188^{+*} \\
(0.079)\end{array}$ & $\begin{array}{c}-0.193^{+*} \\
(0.079)\end{array}$ \\
\hline Education & $\begin{array}{c}-0.094^{+*+} \\
(0.023)\end{array}$ & $\begin{array}{c}-0.086^{* * *} \\
(0.023)\end{array}$ & $\begin{array}{c}-0.085^{*+*} \\
(0.023)\end{array}$ \\
\hline Female & $\begin{array}{c}0.153^{* *} \\
(0.065)\end{array}$ & $\begin{array}{l}0.151^{* *} \\
(0.065)\end{array}$ & $\begin{array}{l}0.137^{* *} \\
(0.065)\end{array}$ \\
\hline Threat & $\begin{array}{c}0.298^{+* *} \\
(0.032)\end{array}$ & $\begin{array}{c}0.340^{+*+} \\
(0.047)\end{array}$ & $\begin{array}{c}0.323^{*+*} \\
(0.048)\end{array}$ \\
\hline Ideology & $\begin{array}{c}0.108^{+*+} \\
(0.019)\end{array}$ & $\begin{array}{c}0.076^{*+*} \\
(0.026)\end{array}$ & $\begin{array}{c}0.079^{+*+} \\
(0.026)\end{array}$ \\
\hline Time 2 & $\begin{array}{c}-0.016 \\
(0.078)\end{array}$ & $\begin{array}{c}0.044 \\
(0.089)\end{array}$ & $\begin{array}{c}0.027 \\
(0.089)\end{array}$ \\
\hline Time 3 & $\begin{array}{c}0.075 \\
(0.078)\end{array}$ & $\begin{array}{c}0.073 \\
(0.083)\end{array}$ & $\begin{array}{c}0.060 \\
(0.083)\end{array}$ \\
\hline Threat X Ideology & & $\begin{array}{c}-0.032^{+} \\
(0.018)\end{array}$ & $\begin{array}{c}-0.058^{+*} \\
(0.025)\end{array}$ \\
\hline Threat X Time 2 & & $\begin{array}{c}-0.066 \\
(0.088)\end{array}$ & $\begin{array}{c}0.070 \\
(0.099)\end{array}$ \\
\hline Threat X Time 3 & & $\begin{array}{c}-0.132^{+} \\
(0.074)\end{array}$ & $\begin{array}{r}-0.125 \\
(0.077)\end{array}$ \\
\hline Ideology X Time 2 & & $\begin{array}{l}0.094^{* *} \\
(0.047)\end{array}$ & $\begin{array}{c}0.066 \\
(0.048)\end{array}$ \\
\hline Ideology X Time 3 & & $\begin{array}{c}0.040 \\
(0.047)\end{array}$ & $\begin{array}{c}0.039 \\
(0.046)\end{array}$ \\
\hline Threat X Ideology X Time 2 & & & $\begin{array}{c}0.153^{+*+} \\
(0.053)\end{array}$ \\
\hline Threat X Ideology X Time 3 & & & $\begin{array}{c}0.009 \\
(0.041)\end{array}$ \\
\hline Constant & $\begin{array}{c}3.470^{*+*} \\
(0.159)\end{array}$ & $\begin{array}{c}3.442^{*+*} \\
(0.159)\end{array}$ & $\begin{array}{c}3.469^{+*+} \\
(0.159)\end{array}$ \\
\hline Observations & 604 & 604 & 604 \\
\hline $\mathrm{R}^{2}$ & 0.242 & 0.254 & 0.265 \\
\hline Adjusted $\mathrm{R}^{2}$ & 0.230 & 0.236 & 0.245 \\
\hline
\end{tabular}


Table 6: Study 1, OLS Regression Results Predicting Liberal Conspiracy Endorsement

\begin{tabular}{|c|c|c|c|}
\hline \multirow[b]{3}{*}{ Income } & \multicolumn{3}{|c|}{ Dependent variable: } \\
\hline & \multicolumn{3}{|c|}{ Liberal Conspiracy Endorsement } \\
\hline & $\begin{array}{c}-0.0005 \\
(0.009)\end{array}$ & $\begin{array}{l}-0.001 \\
(0.009)\end{array}$ & $\begin{array}{r}-0.002 \\
(0.009)\end{array}$ \\
\hline Age & $\begin{array}{c}-0.004 \\
(0.003)\end{array}$ & $\begin{array}{c}-0.003 \\
(0.003)\end{array}$ & $\begin{array}{l}-0.003 \\
(0.003)\end{array}$ \\
\hline White & $\begin{array}{c}-0.158^{* 4} \\
(0.063)\end{array}$ & $\begin{array}{c}-0.141^{*+} \\
(0.064)\end{array}$ & $\begin{array}{c}-0.144^{*+} \\
(0.064)\end{array}$ \\
\hline Education & $\begin{array}{l}-0.016 \\
(0.018)\end{array}$ & $\begin{array}{c}-0.013 \\
(0.019)\end{array}$ & $\begin{array}{l}-0.012 \\
(0.018)\end{array}$ \\
\hline Female & $\begin{array}{c}0.050 \\
(0.052)\end{array}$ & $\begin{array}{c}0.040 \\
(0.052)\end{array}$ & $\begin{array}{c}0.031 \\
(0.052)\end{array}$ \\
\hline Threat & $\begin{array}{c}0.239^{4+*} \\
(0.026)\end{array}$ & $\begin{array}{c}0.206^{* * *} \\
(0.038)\end{array}$ & $\begin{array}{c}0.193^{+* *} \\
(0.039)\end{array}$ \\
\hline Ideology & $\begin{array}{c}-0.135^{* *+} \\
(0.015)\end{array}$ & $\begin{array}{c}-0.121^{*+*} \\
(0.021)\end{array}$ & $\begin{array}{c}-0.120^{*+*} \\
(0.021)\end{array}$ \\
\hline Time 2 & $\begin{array}{c}0.007 \\
(0.063)\end{array}$ & $\begin{array}{c}0.001 \\
(0.072)\end{array}$ & $\begin{array}{l}-0.012 \\
(0.072)\end{array}$ \\
\hline Time 3 & $\begin{array}{l}0.135^{*+} \\
(0.063)\end{array}$ & $\begin{array}{c}0.090 \\
(0.067)\end{array}$ & $\begin{array}{c}0.080 \\
(0.067)\end{array}$ \\
\hline Threat X Ideology & & $\begin{array}{c}-0.027^{*} \\
(0.015)\end{array}$ & $\begin{array}{c}-0.047^{*+} \\
(0.020)\end{array}$ \\
\hline Threat X Time 2 & & $\begin{array}{c}0.091 \\
(0.071)\end{array}$ & $\begin{array}{l}0.181^{*+} \\
(0.080)\end{array}$ \\
\hline Threat X Time 3 & & $\begin{array}{l}-0.007 \\
(0.060)\end{array}$ & $\begin{array}{c}0.002 \\
(0.062)\end{array}$ \\
\hline Ideology X Time 2 & & $\begin{array}{c}0.013 \\
(0.038)\end{array}$ & $\begin{array}{l}-0.005 \\
(0.039)\end{array}$ \\
\hline Ideology X Time 3 & & $\begin{array}{l}-0.048 \\
(0.038)\end{array}$ & $\begin{array}{l}-0.049 \\
(0.038)\end{array}$ \\
\hline Threat X Ideology X Time 2 & & & $\begin{array}{l}0.103^{+*} \\
(0.043)\end{array}$ \\
\hline Threat X Ideology X Time 3 & & & $\begin{array}{c}0.014 \\
(0.033)\end{array}$ \\
\hline Constant & $\begin{array}{c}3.477^{+*+} \\
(0.128)\end{array}$ & $\begin{array}{c}3.462^{*+*} \\
(0.128)\end{array}$ & $\begin{array}{c}3.481^{*+*} \\
(0.128)\end{array}$ \\
\hline Observations & 604 & 604 & 604 \\
\hline $\mathrm{R}^{2}$ & 0.231 & 0.241 & 0.248 \\
\hline Adjusted $\mathrm{R}^{2}$ & 0.220 & 0.223 & 0.228 \\
\hline
\end{tabular}


Table 7: Study 1, OLS Regression Results Predicting Conservative Conspiracy Endorsement

\begin{tabular}{|c|c|c|c|}
\hline & \multicolumn{3}{|c|}{ Dependent variable: } \\
\hline & Conservative & e Conspiracy & Endorsement \\
\hline Income & $\begin{array}{c}0.006 \\
(0.010)\end{array}$ & $\begin{array}{c}0.006 \\
(0.010)\end{array}$ & $\begin{array}{c}0.006 \\
(0.010)\end{array}$ \\
\hline Age & $\begin{array}{c}-0.006^{*} \\
(0.003)\end{array}$ & $\begin{array}{c}-0.007^{+4} \\
(0.003)\end{array}$ & $\begin{array}{c}-0.007^{* *} \\
(0.003)\end{array}$ \\
\hline White & $\begin{array}{c}-0.135^{+} \\
(0.070)\end{array}$ & $\begin{array}{c}-0.132^{+} \\
(0.071)\end{array}$ & $\begin{array}{c}-0.132^{*} \\
(0.071)\end{array}$ \\
\hline Education & $\begin{array}{c}-0.082^{*+*} \\
(0.021)\end{array}$ & $\begin{array}{c}-0.076^{+*+*} \\
(0.021)\end{array}$ & $\begin{array}{c}-0.076^{*+*} \\
(0.021)\end{array}$ \\
\hline Female & $\begin{array}{c}0.008 \\
(0.058)\end{array}$ & $\begin{array}{c}0.021 \\
(0.058)\end{array}$ & $\begin{array}{c}0.022 \\
(0.058)\end{array}$ \\
\hline Threat & $\begin{array}{c}0.203^{+*+} \\
(0.029)\end{array}$ & $\begin{array}{c}0.325^{*+*} \\
(0.042)\end{array}$ & $\begin{array}{c}0.329^{*+*} \\
(0.043)\end{array}$ \\
\hline Ideology & $\begin{array}{c}0.329^{+*+} \\
(0.017)\end{array}$ & $\begin{array}{c}0.288^{*+*} \\
(0.023)\end{array}$ & $\begin{array}{c}0.288^{*+*} \\
(0.023)\end{array}$ \\
\hline Time 2 & $\begin{array}{l}-0.062 \\
(0.070)\end{array}$ & $\begin{array}{l}-0.005 \\
(0.080)\end{array}$ & $\begin{array}{l}-0.002 \\
(0.080)\end{array}$ \\
\hline Time 3 & $\begin{array}{l}-0.109 \\
(0.070)\end{array}$ & $\begin{array}{l}-0.071 \\
(0.074)\end{array}$ & $\begin{array}{l}-0.068 \\
(0.075)\end{array}$ \\
\hline Threat X Ideology & & $\begin{array}{c}0.014 \\
(0.016)\end{array}$ & $\begin{array}{c}0.019 \\
(0.022)\end{array}$ \\
\hline Threat X Time 2 & & $\begin{array}{c}-0.195^{*+} \\
(0.079)\end{array}$ & $\begin{array}{c}-0.209^{* *} \\
(0.089)\end{array}$ \\
\hline Threat X Time 3 & & $\begin{array}{c}-0.222^{+*+} \\
(0.066)\end{array}$ & $\begin{array}{c}-0.227^{* *+} \\
(0.070)\end{array}$ \\
\hline Ideology X Time 2 & & $\begin{array}{c}0.059 \\
(0.042)\end{array}$ & $\begin{array}{c}0.062 \\
(0.043)\end{array}$ \\
\hline Ideology X Time 3 & & $\begin{array}{c}0.069^{+} \\
(0.042)\end{array}$ & $\begin{array}{c}0.070^{+} \\
(0.042)\end{array}$ \\
\hline Threat X Ideology X Time 2 & & & $\begin{array}{l}-0.017 \\
(0.048)\end{array}$ \\
\hline Threat X Ideology X Time 3 & & & $\begin{array}{l}-0.009 \\
(0.037)\end{array}$ \\
\hline Constant & $\begin{array}{c}3.185^{*+*} \\
(0.143)\end{array}$ & $\begin{array}{c}3.173^{+*+} \\
(0.142)\end{array}$ & $\begin{array}{c}3.170^{+* *} \\
(0.143)\end{array}$ \\
\hline Observations & 604 & 604 & 604 \\
\hline $\mathrm{R}^{2}$ & 0.473 & 0.488 & 0.488 \\
\hline Adjusted $\mathrm{R}^{2}$ & 0.465 & 0.476 & 0.474 \\
\hline
\end{tabular}




\section{A7: Study 2 Descriptive Statistics (Time 1, Time 2, Time 3)}

Table 8: Study 2, Time 1 Descriptive Statistics

\begin{tabular}{lccccc}
\hline \hline Statistic & $\mathrm{N}$ & Mean & St. Dev. & Min & Max \\
\hline General Conspiracy Endorsement & 160 & 2.604 & 0.745 & 1.000 & 4.733 \\
Liberal Conspiracy Endorsement & 160 & 2.816 & 0.649 & 1.000 & 4.700 \\
Conservative Conspiracy Endorsement & 160 & 2.465 & 0.790 & 1.000 & 4.500 \\
Threat & 160 & 2.781 & 0.831 & 1.000 & 5.000 \\
Ideology & 160 & 4.162 & 1.805 & 1 & 7 \\
Income & 160 & 9.150 & 3.572 & 1 & 15 \\
Age & 160 & 19.494 & 2.408 & 17 & 36 \\
White & 160 & 0.894 & 0.309 & 0 & 1 \\
Education & 160 & 2.831 & 0.656 & 1 & 6 \\
Female & 160 & 0.588 & 0.494 & 0 & 1 \\
\hline
\end{tabular}

Table 9: Study 2, Time 2 Descriptive Statistics

\begin{tabular}{lccccc}
\hline \hline Statistic & $\mathrm{N}$ & Mean & St. Dev. & Min & Max \\
\hline General Conspiracy Endorsement & 212 & 2.648 & 0.711 & 1.000 & 4.600 \\
Liberal Conspiracy Endorsement & 212 & 2.892 & 0.698 & 1.000 & 4.900 \\
Conservative Conspiracy Endorsement & 212 & 2.458 & 0.855 & 1.000 & 4.600 \\
Threat & 212 & 2.807 & 0.953 & 1.000 & 5.000 \\
Ideology & 212 & 4.203 & 1.780 & 1 & 7 \\
Income & 212 & 8.962 & 3.717 & 1 & 15 \\
Age & 212 & 19.571 & 1.932 & 17 & 32 \\
White & 212 & 0.896 & 0.306 & 0 & 1 \\
Education & 212 & 2.816 & 0.567 & 1 & 5 \\
Female & 212 & 0.443 & 0.498 & 0 & 1 \\
\hline
\end{tabular}

Table 10: Study 2, Time 3 Descriptive Statistics

\begin{tabular}{lccccc}
\hline \hline Statistic & $\mathrm{N}$ & Mean & St. Dev. & Min & Max \\
\hline General Conspiracy Endorsement & 273 & 2.477 & 0.701 & 1.000 & 4.667 \\
Liberal Conspiracy Endorsement & 273 & 2.715 & 0.715 & 1.000 & 4.800 \\
Conservative Conspiracy Endorsement & 273 & 2.263 & 0.819 & 1.000 & 4.500 \\
Threat & 273 & 2.606 & 0.874 & 1.000 & 5.000 \\
Ideology & 273 & 4.062 & 1.875 & 1 & 7 \\
Income & 273 & 9.081 & 3.946 & 1 & 15 \\
Age & 273 & 19.927 & 2.409 & 17 & 45 \\
White & 273 & 0.890 & 0.313 & 0 & 1 \\
Education & 273 & 2.879 & 0.518 & 1 & 5 \\
Female & 273 & 0.542 & 0.499 & 0 & 1 \\
\hline
\end{tabular}




\section{A8: Study 2 Statistical Models}

Table 11: Study 2, Mixed Effects ANOVA

\begin{tabular}{|c|c|c|c|c|c|}
\hline & $D f$ & Sum Sq & Mean Sq & F value & $\operatorname{Pr}(>\mathrm{F})$ \\
\hline \multicolumn{6}{|l|}{ Between Subjects } \\
\hline Threat & 1 & 34.39 & 34.39 & 46.99 & $0.000^{* * *}$ \\
\hline Ideology & 1 & 22.27 & 22.27 & 30.43 & $0.000^{* * *}$ \\
\hline Time & 2 & 13.74 & 6.87 & 9.39 & $0.000^{* * *}$ \\
\hline Age & 1 & 0.17 & 0.17 & 0.23 & 0.630 \\
\hline Education & 1 & 1.34 & 1.34 & 1.83 & 0.176 \\
\hline Female & 1 & 0.37 & 0.37 & 0.51 & 0.475 \\
\hline White & 1 & 12.03 & 12.03 & 16.44 & $0.000^{* * *}$ \\
\hline Income & 1 & 3.83 & 3.83 & 5.23 & $0.023^{* *}$ \\
\hline Threat X Ideology & 1 & 0 & 0 & 0 & 0.979 \\
\hline Threat X Time & 2 & 3.11 & 1.55 & 2.12 & 0.120 \\
\hline Ideology X Time & 2 & 3.01 & 1.5 & 2.06 & 0.129 \\
\hline Threat X Ideology X Time & 2 & 0.93 & 0.47 & 0.64 & 0.529 \\
\hline Residuals & 548 & 401.01 & 0.73 & & \\
\hline \multicolumn{6}{|l|}{ Within Subjects } \\
\hline Conspiracy Type & 2 & 48.38 & 24.19 & 117.58 & $0.000^{* * *}$ \\
\hline Threat X Conspiracy Type & 2 & 11.8 & 5.9 & 28.69 & $0.000^{* * *}$ \\
\hline Ideology X Conspiracy Type & 2 & 216.8 & 108.4 & 526.95 & $0.000^{* * *}$ \\
\hline Time X Conspiracy Type & 4 & 0.35 & 0.09 & 0.42 & 0.793 \\
\hline Threat X Ideology X Conspiracy Type & 2 & 2.24 & 1.12 & 5.44 & $0.005^{* * *}$ \\
\hline Threat X Time X Conspiracy Type & 4 & 1.04 & 0.26 & 1.26 & 0.283 \\
\hline Ideology X Time X Conspiracy Type & 4 & 0.86 & 0.21 & 1.04 & 0.385 \\
\hline Threat X Ideology X Time X Conspiracy Type & 4 & 1.2 & 0.3 & 1.46 & 0.214 \\
\hline Residuals & 1106 & 227.52 & 0.21 & & \\
\hline
\end{tabular}


Table 12: Study 2, OLS Regression Results Predicting General Conspiracy Endorsement

\begin{tabular}{|c|c|c|c|}
\hline \multirow[b]{3}{*}{ Income } & \multicolumn{3}{|c|}{ Dependent variable: } \\
\hline & \multicolumn{3}{|c|}{ General Conspiracy Endorsement } \\
\hline & $\begin{array}{c}-0.021^{*+*} \\
(0.007)\end{array}$ & $\begin{array}{c}-0.021^{* * *} \\
(0.007)\end{array}$ & $\begin{array}{c}-0.021^{*+*} \\
(0.008)\end{array}$ \\
\hline Age & $\begin{array}{r}-0.018 \\
(0.013)\end{array}$ & $\begin{array}{l}-0.019 \\
(0.013)\end{array}$ & $\begin{array}{l}-0.019 \\
(0.013)\end{array}$ \\
\hline White & $\begin{array}{c}-0.377^{*+*} \\
(0.089)\end{array}$ & $\begin{array}{c}-0.368^{* * *} \\
(0.090)\end{array}$ & $\begin{array}{c}-0.368^{*+*} \\
(0.090)\end{array}$ \\
\hline Education & $\begin{array}{c}0.025 \\
(0.050)\end{array}$ & $\begin{array}{c}0.030 \\
(0.051)\end{array}$ & $\begin{array}{c}0.030 \\
(0.051)\end{array}$ \\
\hline Female & $\begin{array}{c}0.017 \\
(0.056)\end{array}$ & $\begin{array}{c}0.015 \\
(0.056)\end{array}$ & $\begin{array}{c}0.014 \\
(0.057)\end{array}$ \\
\hline Threat & $\begin{array}{c}0.197^{+*+} \\
(0.031)\end{array}$ & $\begin{array}{c}0.234^{++*} \\
(0.066)\end{array}$ & $\begin{array}{c}0.234^{+*+} \\
(0.066)\end{array}$ \\
\hline Ideology & $\begin{array}{c}0.042^{*+*} \\
(0.015)\end{array}$ & $\begin{array}{c}0.018 \\
(0.031)\end{array}$ & $\begin{array}{c}0.018 \\
(0.031)\end{array}$ \\
\hline Time 2 & $\begin{array}{c}0.061 \\
(0.073)\end{array}$ & $\begin{array}{c}0.074 \\
(0.073)\end{array}$ & $\begin{array}{c}0.075 \\
(0.074)\end{array}$ \\
\hline Time 3 & $\begin{array}{c}-0.117^{*} \\
(0.068)\end{array}$ & $\begin{array}{l}-0.105 \\
(0.069)\end{array}$ & $\begin{array}{l}-0.106 \\
(0.069)\end{array}$ \\
\hline Threat X Ideology & & $\begin{array}{c}0.008 \\
(0.016)\end{array}$ & $\begin{array}{c}0.010 \\
(0.035)\end{array}$ \\
\hline Threat $\mathrm{X}$ Time 2 & & $\begin{array}{c}-0.114 \\
(0.083)\end{array}$ & $\begin{array}{l}-0.115 \\
(0.083)\end{array}$ \\
\hline Threat X Time 3 & & $\begin{array}{c}0.030 \\
(0.082)\end{array}$ & $\begin{array}{c}0.030 \\
(0.082)\end{array}$ \\
\hline Ideology X Time 2 & & $\begin{array}{c}0.011 \\
(0.041)\end{array}$ & $\begin{array}{c}0.010 \\
(0.041)\end{array}$ \\
\hline Ideology X Time 3 & & $\begin{array}{c}0.049 \\
(0.038)\end{array}$ & $\begin{array}{c}0.049 \\
(0.038)\end{array}$ \\
\hline Threat X Ideology X Time 2 & & & $\begin{array}{c}-0.001 \\
(0.045)\end{array}$ \\
\hline Threat X Ideology X Time 3 & & & $\begin{array}{l}-0.005 \\
(0.043)\end{array}$ \\
\hline Constant & $\begin{array}{c}3.384^{+*+} \\
(0.285)\end{array}$ & $\begin{array}{c}3.395^{+*+} \\
(0.286)\end{array}$ & $\begin{array}{c}3.395^{+*+} \\
(0.286)\end{array}$ \\
\hline Observations & 645 & 645 & 645 \\
\hline $\mathrm{R}^{2}$ & 0.134 & 0.142 & 0.142 \\
\hline Adjusted $\mathrm{R}^{2}$ & 0.122 & 0.123 & 0.120 \\
\hline
\end{tabular}


Table 13: Study 2, OLS Regression Results Predicting Liberal Conspiracy Endorsement

\begin{tabular}{|c|c|c|c|}
\hline & \multicolumn{3}{|c|}{ Dependent variable: } \\
\hline & \multicolumn{3}{|c|}{ Liberal Conspiracy Endorsement } \\
\hline & (1) & (2) & (3) \\
\hline Income & $\begin{array}{r}-0.012^{*} \\
(0.007)\end{array}$ & $\begin{array}{r}-0.012^{*} \\
(0.007)\end{array}$ & $\begin{array}{r}-0.012^{*} \\
(0.007)\end{array}$ \\
\hline Age & $\begin{array}{l}-0.008 \\
(0.012)\end{array}$ & $\begin{array}{l}-0.008 \\
(0.012)\end{array}$ & $\begin{array}{l}-0.009 \\
(0.012)\end{array}$ \\
\hline White & $\begin{array}{c}-0.303^{* * *} \\
(0.079)\end{array}$ & $\begin{array}{c}-0.297^{* *+} \\
(0.080)\end{array}$ & $\begin{array}{c}-0.303^{+*+} \\
(0.080)\end{array}$ \\
\hline Education & $\begin{array}{c}0.050 \\
(0.045)\end{array}$ & $\begin{array}{c}0.049 \\
(0.045)\end{array}$ & $\begin{array}{c}0.053 \\
(0.045)\end{array}$ \\
\hline Female & $\begin{array}{l}-0.055 \\
(0.050)\end{array}$ & $\begin{array}{l}-0.050 \\
(0.050)\end{array}$ & $\begin{array}{l}-0.059 \\
(0.050)\end{array}$ \\
\hline Threat & $\begin{array}{c}0.123^{*+*} \\
(0.028)\end{array}$ & $\begin{array}{l}0.116^{*+} \\
(0.058)\end{array}$ & $\begin{array}{l}0.128^{*+} \\
(0.059)\end{array}$ \\
\hline Ideology & $\begin{array}{c}-0.154^{+* 4} \\
(0.014)\end{array}$ & $\begin{array}{c}-0.182^{* *} \\
(0.027)\end{array}$ & $\begin{array}{r}-0.188^{++*} \\
(0.027)\end{array}$ \\
\hline Time 2 & $\begin{array}{c}0.099 \\
(0.064)\end{array}$ & $\begin{array}{c}0.090 \\
(0.065)\end{array}$ & $\begin{array}{c}0.098 \\
(0.065)\end{array}$ \\
\hline Time 3 & $\begin{array}{c}-0.117^{*} \\
(0.060)\end{array}$ & $\begin{array}{c}-0.130^{*+} \\
(0.061)\end{array}$ & $\begin{array}{c}-0.133^{*+} \\
(0.061)\end{array}$ \\
\hline Threat X Ideology & & $\begin{array}{l}-0.021 \\
(0.014)\end{array}$ & $\begin{array}{c}0.033 \\
(0.031)\end{array}$ \\
\hline Threat X Time 2 & & $\begin{array}{r}-0.041 \\
(0.073)\end{array}$ & $\begin{array}{l}-0.052 \\
(0.074)\end{array}$ \\
\hline Threat X Time 3 & & $\begin{array}{c}0.075 \\
(0.073)\end{array}$ & $\begin{array}{c}0.063 \\
(0.073)\end{array}$ \\
\hline Ideology X Time 2 & & $\begin{array}{c}0.039 \\
(0.036)\end{array}$ & $\begin{array}{c}0.045 \\
(0.036)\end{array}$ \\
\hline Ideology X Time 3 & & $\begin{array}{c}0.045 \\
(0.034)\end{array}$ & $\begin{array}{c}0.048 \\
(0.034)\end{array}$ \\
\hline Threat X Ideology X Time 2 & & & $\begin{array}{l}-0.058 \\
(0.040)\end{array}$ \\
\hline Threat X Ideology X Time 3 & & & $\begin{array}{c}-0.077^{*+} \\
(0.038)\end{array}$ \\
\hline Constant & $\begin{array}{c}3.255^{*+*} \\
(0.253)\end{array}$ & $\begin{array}{c}3.256^{*+*} \\
(0.253)\end{array}$ & $\begin{array}{c}3.268^{* *} \\
(0.253)\end{array}$ \\
\hline Obscrvations & 645 & 645 & 645 \\
\hline $\mathrm{R}^{2}$ & 0.273 & 0.282 & 0.286 \\
\hline Adjusted $\mathrm{R}^{2}$ & 0.263 & 0.266 & 0.268 \\
\hline
\end{tabular}


Table 14: Study 2, OLS Regression Results Predicting Conservative Conspiracy Endorsement

\begin{tabular}{|c|c|c|c|}
\hline & \multicolumn{3}{|c|}{ Dependent variable: } \\
\hline & Conservati & e Conspira & Endorsement \\
\hline & (1) & (2) & (3) \\
\hline Income & $\begin{array}{c}-0.014^{+*} \\
(0.007)\end{array}$ & $\begin{array}{c}-0.014^{+*} \\
(0.007)\end{array}$ & $\begin{array}{c}-0.014^{* *} \\
(0.007)\end{array}$ \\
\hline Age & $\begin{array}{l}-0.012 \\
(0.012)\end{array}$ & $\begin{array}{r}-0.013 \\
(0.012)\end{array}$ & $\begin{array}{l}-0.013 \\
(0.012)\end{array}$ \\
\hline White & $\begin{array}{c}-0.227^{+* *} \\
(0.082)\end{array}$ & $\begin{array}{c}-0.211^{* *} \\
(0.082)\end{array}$ & $\begin{array}{c}-0.221^{+* *} \\
(0.082)\end{array}$ \\
\hline Education & $\begin{array}{c}-0.006 \\
(0.046)\end{array}$ & $\begin{array}{c}0.003 \\
(0.046)\end{array}$ & $\begin{array}{c}0.004 \\
(0.046)\end{array}$ \\
\hline Female & $\begin{array}{c}-0.111^{* *} \\
(0.051)\end{array}$ & $\begin{array}{c}-0.108^{+*} \\
(0.051)\end{array}$ & $\begin{array}{c}-0.111^{* *} \\
(0.052)\end{array}$ \\
\hline Threat & $\begin{array}{c}0.135^{* *+} \\
(0.029)\end{array}$ & $\begin{array}{c}0.241^{*+*} \\
(0.060)\end{array}$ & $\begin{array}{c}0.244^{+* *} \\
(0.060)\end{array}$ \\
\hline Ideology & $\begin{array}{c}0.298^{*+*} \\
(0.014)\end{array}$ & $\begin{array}{c}0.245^{+* *} \\
(0.028)\end{array}$ & $\begin{array}{c}0.243^{+* *} \\
(0.028)\end{array}$ \\
\hline Time 2 & $\begin{array}{l}-0.022 \\
(0.067)\end{array}$ & $\begin{array}{l}-0.007 \\
(0.067)\end{array}$ & $\begin{array}{l}-0.010 \\
(0.067)\end{array}$ \\
\hline Time 3 & $\begin{array}{c}-0.169^{+*+*} \\
(0.062)\end{array}$ & $\begin{array}{c}-0.145^{* *} \\
(0.063)\end{array}$ & $\begin{array}{c}-0.136^{* *} \\
(0.063)\end{array}$ \\
\hline Threat X Ideology & & $\begin{array}{l}0.027^{*} \\
(0.015)\end{array}$ & $\begin{array}{c}0.044 \\
(0.032)\end{array}$ \\
\hline Threat X Time 2 & & $\begin{array}{c}-0.188^{*+} \\
(0.075)\end{array}$ & $\begin{array}{c}-0.187^{* *} \\
(0.076)\end{array}$ \\
\hline Threat X Time 3 & & $\begin{array}{r}-0.072 \\
(0.075)\end{array}$ & $\begin{array}{l}-0.075 \\
(0.075)\end{array}$ \\
\hline Ideology X Time 2 & & $\begin{array}{l}0.076^{* *} \\
(0.037)\end{array}$ & $\begin{array}{l}0.083^{* *} \\
(0.038)\end{array}$ \\
\hline Ideology X Time 3 & & $\begin{array}{l}0.062^{*} \\
(0.035)\end{array}$ & $\begin{array}{c}0.064^{*} \\
(0.035)\end{array}$ \\
\hline Threat X Ideology X Time 2 & & & $\begin{array}{l}-0.040 \\
(0.041)\end{array}$ \\
\hline Threat X Ideology X Time 3 & & & $\begin{array}{c}-0.008 \\
(0.039)\end{array}$ \\
\hline Constant & $\begin{array}{c}3.060^{+* *} \\
(0.261)\end{array}$ & $\begin{array}{c}3.031^{+* *} \\
(0.260)\end{array}$ & $\begin{array}{c}3.038^{+* *} \\
(0.260)\end{array}$ \\
\hline Observations & 645 & 645 & 645 \\
\hline $\mathrm{R}^{2}$ & 0.453 & 0.465 & 0.466 \\
\hline Adjusted $\mathrm{R}^{2}$ & 0.445 & 0.453 & 0.452 \\
\hline
\end{tabular}




\section{A9: Study 3 Materials}

\section{Conditions:}

Control (safety/security): These days, many people in the United States feel satisfied with the nation's condition. Many citizens feel that the country has reached a high point in terms of social, economic and political factors. It seems that many countries in the world are enjoying worse social, economic, and political conditions than the U.S.

Control (TV): These days, many people find pleasure when they watch TV. More people have access to more entertainment relative to the past. Many people report enjoying watching movies and TV shows. In seems that compared to any other time period it is easier to find something you enjoy watching on TV. More and more people like watching TV.

Threat: These days, many people in the United States feel disappointed with the nation's condition. Many citizens feel that the country has reached a low point in terms of social, economic and political factors. It seems that many countries in the world are enjoying better social, economic, and political conditions than the U.S. More and more American's express less trust in government. Experts believe this is because of the policies enacted by the Republican (Democratic) Party over the past few years.

\section{A10: Study 3 Descriptive Statistics}

Table 15: Study 3, Descriptive Statistics: Control Condition

\begin{tabular}{lccccccc}
\hline \hline Statistic & $\mathrm{N}$ & Mean & St. Dev. & Min & Pctl(25) & Pctl(75) & Max \\
\hline General Conspiracy Endorsement & 929 & 2.885 & 0.925 & 1.000 & 2.267 & 3.467 & 5.000 \\
Democrat Conspiracy Endorsement & 929 & 3.042 & 0.901 & 1.000 & 2.400 & 3.700 & 5.000 \\
Republican Conspiracy Endorsement & 929 & 2.825 & 1.004 & 1.000 & 2.100 & 3.500 & 5.000 \\
Threat & 928 & 2.608 & 1.179 & 1.000 & 2.000 & 3.500 & 5.000 \\
Ideology & 929 & 4.211 & 1.905 & 1 & 3 & 6 & 7 \\
Age & 885 & 46.086 & 16.235 & 17.000 & 33.000 & 59.000 & 87.000 \\
White & 929 & 0.628 & 0.484 & 0 & 0 & 1 & 1 \\
Education & 929 & 4.318 & 1.850 & 1 & 3 & 5 & 8 \\
Female & 925 & 0.507 & 0.500 & 0.000 & 0.000 & 1.000 & 1.000 \\
\hline
\end{tabular}


Table 16: Study 3, Descriptive Statistics: Threat Condition

\begin{tabular}{lccccccc}
\hline \hline Statistic & $\mathrm{N}$ & Mean & St. Dev. & Min & Pctl(25) & Pctl(75) & Max \\
\hline General Conspiracy Endorsement & 496 & 2.948 & 0.902 & 1.000 & 2.333 & 3.533 & 5.000 \\
Democrat Conspiracy Endorsement & 496 & 3.112 & 0.887 & 1.000 & 2.500 & 3.800 & 5.000 \\
Republican Conspiracy Endorsement & 496 & 2.840 & 1.028 & 1.000 & 2.100 & 3.600 & 5.000 \\
Threat & 494 & 2.735 & 1.195 & 1.000 & 2.000 & 3.500 & 5.000 \\
Ideology & 495 & 4.129 & 1.945 & 1.000 & 3.000 & 6.000 & 7.000 \\
Age & 473 & 46.247 & 16.691 & 18.000 & 32.000 & 60.000 & 94.000 \\
White & 496 & 0.613 & 0.488 & 0 & 0 & 1 & 1 \\
Education & 495 & 4.539 & 1.941 & 1.000 & 3.000 & 6.000 & 8.000 \\
Female & 495 & 0.493 & 0.500 & 0.000 & 0.000 & 1.000 & 1.000 \\
\hline
\end{tabular}

